\title{
Immobilization of Spathaspora Passalidarum NRRL Y-27907 in Calcium Alginate Aiming the Production of Second-generation Ethanol
}

\section{Juliane Machado da Silveira}

UFSC: Universidade Federal de Santa Catarina

\section{Lauren Bergmann Soares}

UFSC: Universidade Federal de Santa Catarina

\section{Karina Cesca}

UFSC: Universidade Federal de Santa Catarina

\section{Anderson Felipe Viana da Silva}

UFSC: Universidade Federal de Santa Catarina

\section{Liana Longo}

UFSC: Universidade Federal de Santa Catarina

\section{Eduardo Zanella}

UFSC: Universidade Federal de Santa Catarina

\section{Boris U. Stambuk}

UFSC: Universidade Federal de Santa Catarina

\section{Luiz Eduardo Biazi}

UFSC: Universidade Federal de Santa Catarina Jaciane Lutz lenczak ( $\nabla$ jaciane.ienczak@ufsc.br)

Universidade Federal de Santa Catarina https://orcid.org/0000-0003-4087-8339

\section{Research Article}

Keywords: xylose consumption, productivity, specific xylose uptake rate, sequential batch fermentations

Posted Date: May 5th, 2021

DOl: https://doi.org/10.21203/rs.3.rs-481069/v1

License: (c) (1) This work is licensed under a Creative Commons Attribution 4.0 International License. Read Full License

Version of Record: A version of this preprint was published at BioEnergy Research on July 24th, 2021. See the published version at https://doi.org/10.1007/s12155-021-10309-w. 

3

5

6

7

8

9

10

11

12

13

14

15

16

17

18

19

20

21

22

23

24

25

26

Immobilization of Spathaspora passalidarum NRRL Y-27907 in calcium alginate aiming the production of second-generation ethanol

(1)

Juliane Machado da Silveira ${ }^{\mathrm{a}}$, Lauren Bergmann Soares ${ }^{\mathrm{a}}$, Karina Cesca ${ }^{\mathrm{a}}$, Anderson Felipe Viana da Silva $^{\mathrm{a}}$, Liana Longo ${ }^{\mathrm{a}}$, Eduardo Zanella ${ }^{\mathrm{b}}$, Boris U. Stambuk ${ }^{\mathrm{b}}$, Luiz Eduardo Biazi ${ }^{\mathrm{a},{ }^{*},}$ Jaciane L. Ienczak ${ }^{\mathrm{a},{ }^{*}}$ (1)

${ }^{a}$ Chemical Engineering and Food Engineering Department, Federal University of Santa CatarinaUFSC, Florianópolis, SC 88040-900, Brazil

${ }^{b}$ Biochemistry Department, Federal University of Santa Catarina - UFSC, Florianópolis, SC 88040900, Brazil

*Corresponding author: jaciane.ienczak@ufsc.br - Tel: +55 4837212519

biazi.luizeduardo@gmail.com - Tel: +55 19984237395 
2 The immobilization of $S$. passalidarum in calcium alginate beads for second-generation ethanol 3 production $(\mathrm{E} 2 \mathrm{G})$ was evaluated in a medium that simulated a hemicellulosic hydrolysate of sugarcane 4 bagasse pretreated with diluted sulfuric acid in terms of sugars composition. Three sets of sequential 5 batch fermentations (SBF) were carried out with free cells, or immobilized cells in high (HSC) and 6 moderate (MSC) initial sugar concentration (120 and $70 \mathrm{~g} / \mathrm{L}$, respectively). SBF were characterized by 7 five consecutive batches performed in shaker, at $30{ }^{\circ} \mathrm{C}$ and $110 \mathrm{rpm}$. Better results were observed for 8 the SBF with immobilized cells in MSC medium when compared to HSC ( ${ }^{\prime}{ }_{\mathrm{P} / \mathrm{S}}$ of $0.27 \pm 0.02$ and 0.19 $9 \pm 0.03 \mathrm{~g} / \mathrm{g}$, respectively), in the second batch cycle. The value for $\mathrm{Y}_{\mathrm{P} / \mathrm{S}}$ in MSC was similar to the obtained with free cells $(0.30 \pm 0.02$ to $0.33 \pm 0.02 \mathrm{~g} / \mathrm{g})$. However, Qp was lower for MSC, reaching $0.81 \pm 0.04 \mathrm{~g} / \mathrm{L} . \mathrm{h}$ in in the second batch, while for free cells the $\mathrm{Q}_{\mathrm{P}}$ varied from $1.06 \pm 0.02$ to $1.16 \pm$ $0.22 \mathrm{~g} / \mathrm{L} . \mathrm{h}$. A technique for determining the concentration of immobilized cells in the alginate beads was applied, which made it possible to determine the specific rates for the SBF performed. According to the results obtained, it was possible to demonstrate that $S$. passalidarum can be immobilized in calcium alginate and reuse through SBF, with performance similar to free cells, which can be a good strategy for fermentation of hemicellulosic hydrolysates.

Keywords: xylose consumption; productivity; specific xylose uptake rate; sequential batch fermentations. 


\section{INTRODUCTION}

In the last decades, the use of renewable energy sources has been given emphasis, considering the environmental problems related to the exploration and use of fossil fuels, in addition to the uncertainties and volatilities in the price of oil and the restriction factors in the emissions of carbon dioxide. In this scenario, ethanol is considered an interesting alternative. More precisely, the production of ethanol from lignocellulosic biomass - called second generation ethanol (E2G) - has been identified as a viable option to increase fuel production without exploring food feedstocks nor expand the cultivated area $[1,2]$.

The production of E2G is divided into four main stages: 1) pre-treatment; 2) hydrolysis; 3) fermentation and 4) distillation. The pre-treatment provides deconstruction of the lignocellulosic raw material, solubilizing the sugars contained in hemicellulose structure and allowing chemical and/or enzymatic access to cellulose in the hydrolysis stage [3]. In addition to sugars, pre-treatment can result in the formation of toxic compounds such as acetic acid, furfural, hydroxymethylfurfural and phenolic compounds, which are inhibitors for fermentation $[2,4,5]$. These compounds act in different ways in cell metabolism by decreasing the energy for multiplication and production, causing interference in enzyme activity, damaging the cell membrane and resulting in the death of microorganisms [6-9].

Detoxification, high cell density, fed batch processes, genetic engineering and cell immobilization have been used as strategies in the second-generation ethanol industry, aiming to minimize the effect of these inhibitors in the fermentation process [3, 9]. Immobilization protect cells against toxic compounds, in addition to improving aspects that are often limiting, such as long operating times, stability, difficulty in recovering and reusing microorganisms and better functionality in continuous systems $[10,11]$.

Immobilization can occur through covalent bonding, adsorption or entrapment processes. The method of entrapment is based on the physical trapping of cells within the interior of the matrix [12]. This methodology is the most used because it is simple to perform, capable of retaining a large number of cells in a small volume, besides presenting low toxicity for them. However, there are negative points in the use of this methodology, such as diffusion of substrates and metabolic products through the support and reduction of conversion rates. Thus, it is necessary to optimize the particle size of the 
support, the diffusivity of the species and the cellular concentration in order to minimize the effects [11, $13]$.

The matrix most used for cell immobilization is calcium alginate, due to its biocompatibility and the speed in the gelling process. This material is extracted from seaweed and is composed of Dmanuronic (M) and L-guluronic (G) acids joined by glycosidic bonds. The proportion and distribution of components are determining factors for the mechanical and gelling properties of the formed gel [12, 14]. The beads of calcium alginate are formed by emulsification or extrusion. The procedure for obtaining the beads starts with the preparation of the mixture of cell suspension and sodium alginate (2$4 \% \mathrm{w} / \mathrm{v})$ [15]. Then, this mixture is dripped in calcium chloride $(20-100 \mathrm{mM})$, which is the gelling solution. The interaction between sodium alginate and calcium chloride promotes the formation of beads [15].

Studies have been carried out using the immobilization of microorganisms to improve the process of obtaining E2G. Mishra et al. [16] immobilized Saccharomyces cerevisiae in calcium alginate beads and performed fermentations using non-detoxified rice straw hydrolysate. The results showed that the immobilization resulted in the stability of the process between the third and the $17^{\text {th }}$ cell recycling, reaching good parameters of the fermentation (approximately $30 \mathrm{~g} / \mathrm{L}$ of ethanol with $90 \%$ yield). Pathania et al. [17] used a co-culture of S. cerevisiae and Scheffersomyces stipitis immobilized in sodium alginate beads to ferment apple pomace hemicellulosic hydrolysate. The authors compared the immobilized cells and free cells fermentations and found that there was an increase of, approximately $30 \%$ in the final concentration of ethanol when the process was carried out with immobilized cells. Fermentation yield was also improved with immobilized cells, resulting in a 58\% yield, against only $45 \%$ for free cells. Antunes et al. [18] tested the immobilization of Scheffersomyces shehatae in sodium alginate beads and used the support in sequential batch fermentation of detoxified sugarcane bagasse hemicellulosic hydrolysate. These authors verified that it was possible to perform five sequential batches reusing the beads with immobilized cells without changing the kinetic parameters, demonstrating the stability of the immobilization.

Spathaspora passalidarum has demonstrated great potential in the production of E2G, mainly due to its capacity to consume xylose at high rates [19-22] and present better performance in 
hemicellulosic hydrolysates when compared to other xylose-fermenters yeasts [19-22]. Despite this, there are still challenges in the use of this microorganism in processes for obtaining E2G, like the need for additional nutrients when using hemicellulosic hydrolysates, the necessity of aeration, and the need for cell robustness against hemicellulosic hydrolysate inhibitors [23]. In relation to the last issue, the strategy of cell immobilization could be an alternative to overcome this problem, since immobilized cells are more robust and easy to deal with contamination, in addition to being protected from the action of toxic compounds [2]. However, there are no reports of the application of this yeast in immobilization processes as far as we know. In this context, the objective of this study was to immobilize $S$. passalidarum in calcium alginate beads and compare fermentation parameters of this system with free high cell density system during five sequential batches, aiming to consolidate the process for application in the production of E2G.

\section{MATERIALS AND METHODS}

\section{Microorganism strain}

The strain used was Spathaspora passalidarum NRRL Y-27907. The microorganism was stored in YPDX medium (1\% yeast extract; $2 \%$ peptone; $1 \%$ dextrose; and $1 \%$ xylose, in w/v) with glycerol (1:1 v/v) at $-80^{\circ} \mathrm{C}$.

\section{Cell propagation for a high cell density yeast solution}

S. passalidarum was reactivated by adding $2 \mathrm{~mL}$ of stock cells in $0.1 \mathrm{~L}$ of YPDX medium, and incubated for $24 \mathrm{~h}$, at $30{ }^{\circ} \mathrm{C}$ and $150 \mathrm{rpm}$ (Tecnal - TE424) [24]. After that, $15 \mathrm{~mL}$ of this culture (corresponding to $10 \%$ of total volume) were transferred to the inoculum medium containing (g/L): 5 yeast extract, 5 peptone, 1.32 dextrose, 12 xylose, 2.3 urea, $2 \mathrm{KH}_{2} \mathrm{PO}_{4}$ and $0.3 \mathrm{MgSO}_{4} .7 \mathrm{H}_{2} \mathrm{O}$ [24][24], and incubated under the same conditions [24]. The propagation occurred in 0.5 L Erlenmeyer flasks with $0.2 \mathrm{~L}$ of working volume. Propagation was carried out at $150 \mathrm{rpm}, 30{ }^{\circ} \mathrm{C}$ and $40 \mathrm{~h}$ with a pulse of $15 \mathrm{~g} / \mathrm{L}$ of glucose at $15 \mathrm{~h}$. The medium composition was adapted based on Santos et al [24], and contained (g/L): 30 glucose, 3 yeast extract, 5 peptone, 30 dextrose, 5 urea and $2 \mathrm{KH}_{2} \mathrm{PO}_{4}$. After finishing this process, the entire volume was separated by centrifugation (Quimis Q222T) at $3000 g$ for 
5 min. Supernatant was discarded and biomass washed with sterile distilled water, then separated again under the same conditions. The concentrated cells were resuspended in sterile distilled water and stored under refrigeration for later use.

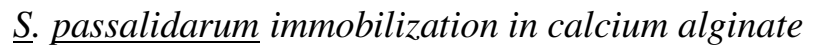

An amount of $35 \mathrm{~mL}$ of cell suspension obtained in the propagation system was added to $25 \mathrm{~mL}$ of $4.8 \%$ sodium alginate sterile solution, resulting in a solution with $2 \%$ alginate and a total cell mass of $4 \mathrm{~g}$, corresponding to $20 \mathrm{~g} / \mathrm{L}$ of cells in the fermentation. This mixture was dripped $(2 \mathrm{~mL} / \mathrm{h})$ with a peristaltic pump (Watson-Marlow 120S) in $2 \% \mathrm{CaCl}_{2}$ to produce the beads [25-27]. Beads were kept in $2 \% \mathrm{CaCl}_{2}$ solution for $16 \mathrm{~h}$ to cure [16]. Afterward, the alginate beads were washed with sterile distilled water and used for fermentation and recycling. The beads obtained from the $60 \mathrm{~mL}$ mixture were counted, resulting in 940 .

\section{Sequential batch fermentation with cell recycling}

Two sets of sequential batch fermentations (SBF) were performed by using immobilized $S$. passalidarum cells and one with free cells. The first set for immobilized cells fermentations was based on high initial sugars content (HSC) with, approximately $120 \mathrm{~g} / \mathrm{L}$ of sugars (Table 1 ). The second one with moderate initial sugars (MSC) had, approximately $70 \mathrm{~g} / \mathrm{L}$ of sugars (Table 1). SBD with free cells had $\sim 85 \mathrm{~g} / \mathrm{l}$ of initial sugar content (Table 1). Five sequential batch fermentations were carried out in 500-mL Erlenmeyer flasks (in triplicate), with $200 \mathrm{~mL}$ of working volume for all conditions tested. The initial concentration of cells in the fermentation medium was defined as $20 \mathrm{~g} / \mathrm{L}$ for all conditions tested, and the composition of the medium to HSC, MSC and free cells SBF was (g/L): 3.0 yeast extract, 2.3 urea, $0.1 \mathrm{CaCl}_{2}$ and $1.0 \mathrm{MgSO}_{4} .7 \mathrm{H}_{2} \mathrm{O}$. Sugar content for $\mathrm{HSC}$ and MSC were based on Nikolic et al. [14] and Neitzel et al. [28], respectively. A proportion of 30\% glucose and 70\% xylose was applied in all fermentations according to Neitzel et al. [28], with the aim to simulate sugars content of hemicellulosic hydrolysate obtained from sugarcane bagasse sulfuric acid pre-treatment [29]. Sugar content for each SBF performed is presented in Table 1. 
2 [16]. SBF were carried out in a shaker (Tecnal TE-424), at $30^{\circ} \mathrm{C}, 24 \mathrm{~h}$ and $110 \mathrm{rpm}$, according to [30].

3 At the end of each batch with immobilized cells, beads were separated with a sieve and washed with

4 distilled water, and then added in a new medium to perform the next batch. For free cells fermentation,

5 the medium was centrifuged (Quimis Q222T, $3000 \mathrm{~g}$ ) precipitated material was washed as described

6 before, supernatant was discarded and the biomass was added in a new medium to perform the next 7 batch.

At each fermentation, samples were collected at times $0,12,18$ and $24 \mathrm{~h}$ for analytical sugar and products determinations by High Performance Liquid Chromatography (HPLC) [24] and pH. The immobilized cells concentration was determined at the beginning and end of each batch as described in the next topic. At the end of batches 3 and 5, beads were sampled for morphological analysis in a Scanning Electron Microscope (SEM).

\section{[Table 1]}

\section{Determination of immobilized cells concentration by spectrophotometry}

The concentration of immobilized cells within calcium alginate beads at the initial $(0 \mathrm{~h})$ and final ( $24 \mathrm{~h}$ ) time of each batch was determined by dissolving 5 beads into $10 \mathrm{~mL}$ of $1 \%$ sodium citrate [31]. The spectrophotometer (Hitachi U-2900) was used to determine the absorbance of prepared mixtures at $600 \mathrm{~nm}$ wavelength. From this data, the cell mass contained into the 5 beads sampled could be achieved using Equation 1.

$$
\mathrm{m}_{5}=\left[\left(\left(a b s_{M} \times F D\right)-a b s_{B}\right) \times 0.2305\right] \times \mathrm{V}_{\mathrm{M}}
$$

Where $\mathrm{m}_{5}$ is the cells mass in 5 beads, $\mathrm{Abs}_{\mathrm{M}}$ is the mixture absorbance, $\mathrm{F}_{\mathrm{D}}$ is the dilution factor, $a b s_{B}$ is the blank absorbance, $\mathrm{V}_{\mathrm{M}}$ is the mixture volume $(0.01 \mathrm{~L})$ and 0.2305 is the standard curve decline.

To determine the cell concentration of samples collected during fermentation, Equation 2 was used.

$$
\text { C cells } \text { immobilized }=\frac{\mathrm{m}_{5} \times \frac{\mathrm{n}^{\circ} \text { of total beads }}{\mathrm{n}^{\circ} \text { of sampled beads }}}{V_{\mathrm{F}}}
$$


fermentation volume $(0.02 \mathrm{~L})$.

\section{Determination of free cell and analytes concentration}

Free cell concentration was determined by spectrophotometer at $600 \mathrm{~nm}$ wavelength. Based on a standard Abs versus dry cell weight relation previously stablished by our team, it was possible to estimate dry cell weight content. The concentrations of xylose, glucose, ethanol, acetic acid, xylitol and glycerol were determined by high-performance liquid chromatography (HPLC) as described by Bonan et al. [32].

\section{Morphological analysis of calcium alginate beads}

The morphology of calcium alginate beads containing the $S$. passalidarum cells was analyzed by Scanning Electron Microscopy (SEM). The preparation of beads consisted of submersion in $2.5 \%$ glutaraldehyde for $2 \mathrm{~h}$ to fix the cells and washed with PBS solution. Afterwards, they were dehydrated with ethanol solution $(10,30,50,70,80,90$ and 100\%) for 20 min each [33]. Posteriorly, samples were dried using critical point dryer equipment (Leica) and they were mounted on a carbon tape under aluminum stubs and covered with a thin layer of gold. The evaluation of beads was carried using micrographs at magnifications between 25 and 5000X, and electron beams with $10 \mathrm{kV}$ of energy.

\section{Fermentation kinetic parameters}

The ethanol yield factor $\left(\mathrm{Y}_{\mathrm{P} / \mathrm{S}}, \mathrm{g} / \mathrm{g}\right)$ was calculated by ethanol produced $(\mathrm{g} / \mathrm{L})$ divided by the sugars consumed $(\mathrm{g} / \mathrm{L})$. The modified yield factor $\left(\mathrm{Y}^{\prime} \mathrm{P} / \mathrm{S}, \mathrm{g} / \mathrm{g}\right)$ was calculated by ethanol produced $(\mathrm{g} / \mathrm{L})$ divided by the initial sugar concentration $(\mathrm{g} / \mathrm{L})$. The theoretical percentage yields $(\mathrm{n}, \%)$ was calculated from the yield factor divided by the theoretical yield of ethanol production $(0.511 \mathrm{~g} / \mathrm{g})$, multiplied by 100. Ethanol productivity was calculated by metabolite produced $(\mathrm{g} / \mathrm{L})$ divided by the fermentation time (h). The specific rates $\left(\mu_{\mathrm{Xyl}}, \mu_{\mathrm{Glu}}\right.$ and $\left.\mu_{\mathrm{EtOH}}, \mathrm{g} / \mathrm{g} . \mathrm{h}\right)$ were calculated by a second-degree polynomial arrange for each component and divided by the cell concentration on that time. The kinetic data of the 
fermentations were submitted to analysis of variance (ANOVA) and the means were compared by the Tukey test $(\mathrm{p}<0.05)$, using OriginPro software 8.5 (OriginLab, USA).

\section{RESULTS AND DISCUSSION}

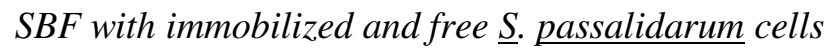

Fig. 1 shows the concentration profiles of glucose, xylose, cells and ethanol for SBF with free cells (Fig. 1a) and immobilized cells (Fig. 1b and 1c). The cell concentration for the immobilized cells is presented as total cells in the fermentations, which corresponds to the sum of the immobilized cells inside the calcium alginate beads and the cells suspended in the medium (desorbed). In this section, a comparison between free (Fig. 1a) and immobilized cells fermented at moderate (MSC) initial sugar concentration (Fig. 1b) will be made, due to similar initial sugar concentration of these two sets of SBF ( $\sim 70$ and $\sim 85 \mathrm{~g} / \mathrm{L}$ ). It is possible to observe that glucose was totally consumed in all conditions and all batches. The simultaneous consumption of xylose and glucose was observed for fermentation with immobilized cells (Fig. 1b) between 0 and $6 \mathrm{~h}$ of fermentation. This behavior was observed only for this condition due to the greater number of samples collected, which does not discard the possibility that the same behavior may have occurred in fermentations with free cells. Long et al. [36] and Hou [22] reported the same behavior for sugar consumption, who used free cells of $S$. passalidarum at the initial concentration of $1.23 \mathrm{~g} / \mathrm{L}$. However, the effect of catabolite repression, characterized by the sequential consumption of glucose and xylose is reported in the literature for this microorganism [23, 34, 40, 41]. Catabolite repression is observed in the metabolism of most microorganisms and is the phenomenon that occurs when the consumption of glucose present in the environment prevents the expression of genes that encode enzymes necessary for the metabolization of other sugars [36].

[Fig. 1]

In Fig. 1a it is still possible to observe that xylose consumption was practically complete for SBF with free cells, with the maximum value for residual sugar being $4.33 \pm 0.25 \mathrm{~g} / \mathrm{L}$ in $\mathrm{B} 1$. In contrast, $24 \mathrm{~h}$ of fermentation was not sufficient for the complete consumption of xylose for SBF in MSC with immobilized cells, with a maximum residual sugar of $29.54 \pm 2.50 \mathrm{~g} / \mathrm{L}$ in B5 (Fig. 1b). For the assay with free cells, the reuse of the cells seems to have improved xylose consumption, since in B1 there was 
residual xylose and in B2 this sugar was consumed after $18 \mathrm{~h}$, while from B3 to B5 the complete consumption of xylose occurred before $18 \mathrm{~h}$ of fermentation. This behavior was not observed for SBF in MSC with immobilized cells (Fig 1b), in which the reuse of the cells hindered the consumption of xylose, causing incomplete sugar consumption over the course of the batches.

The final concentration of ethanol obtained for SBF (Table 2) was higher for the free cells, when compared to MSC immobilized cells and reaching its maximum value in B1 $(35.5 \pm 0.01 \mathrm{~g} / \mathrm{L})$. The concentration was slightly lower in the other batches, but remained approximately constant, ranging from 29.82 to $31.43 \mathrm{~g} / \mathrm{L}$. For SBF with immobilized cells (Fig 1b), the highest concentration obtained was in $\mathrm{B} 2(21.60 \pm 1.34 \mathrm{~g} / \mathrm{L})$, with a decrease in subsequent batches. It was possible to observe that the ethanol production profile for free cells changes when sugar consumption changes from glucose to xylose, which does not happen with immobilized cells, which remain at the same production rate (slope of ethanol production).

[Table 2]

According to Ndubuisi et al. [37], although immobilization in calcium alginate gives advantages to the fermentation process, such as ease of reuse and cell protection against inhibitors and stressful environmental conditions, the support may present resistance to mass transfer, making it difficult to use for many batches. It could explain the difference between the consumption of sugars between SBF with free cells and immobilized cells, as well as the difficulty in metabolizing xylose for fermentation with immobilized cells, highlighted in the final batches (B4 and B5). Mass transfer can be hampered by immobilization in alginate, impairing the transport of substrate. Another important nutrient for E2G production by $S$. passalidarum that deserves attention is oxygen.

Microorganisms that have the Crabtree effect produce ethanol when sugar concentrations are high, even in aerobic conditions. S. passalidarum is a Crabtree negative yeast, and cell production increases with higher aeration, and the choice to produce ethanol or cells depends on the concentration of $\mathrm{O}_{2}$ available to the cells $[35,38]$. In the case of the SBF with immobilized cells used in this work (shaker), the oxygen transfer was probable impaired due to the bioreactor and support choice, making it difficult to consume xylose and, consequently, to produce ethanol. Portugal-Nunes et al. [39] investigated the effect of $S$. stipitis immobilization for ethanol production. They reported that the 
calcium alginate support limited the mass transfer based on the difference in glucose uptake rate between the free and immobilized cells fermentations. According to these authors, the glucose uptake rate was 1.5 times higher for free cells in relation to immobilized cells.

Cells concentration for SBF with free cells (Fig. 1a) were approximately $20 \mathrm{~g} / \mathrm{L}$ at the beginning of B1. Low cell growth was observed in the five SBF with free cells, and all SBF showed constancy for the initial cell concentration (approximately $20 \mathrm{~g} / \mathrm{L}$ ), probably due to $\mathrm{O}_{2}$ limitation caused by bioreactor choice (shaker) [20,38]. It is important to highlight that there was no purge in SBF with free cells and all the cells present in the previous batch were transferred to a subsequent batch.

Cells concentration for SBF with immobilized cells (Fig. 2) showed an increase in free cells higher than that observed for the free cells system (Fig. 1a). This behavior may have occurred due to cells desorption from the surface of the support, and subsequently budding when these cells are free in the culture medium, where $\mathrm{O}_{2}$ availability probably was superior to the $\mathrm{O}_{2}$ supply inside alginate beads pores. Fermentations performed in systems with an adequate supply of O2 (STR, continuous fluidized bed reactor, for example) could lead to better results of cell growth (renewal) and xylose consumption.

[Fig. 2]

Table 2 shows the kinetic parameters of SBF with free cells and immobilized cells in MSC. For SBF with immobilized cells, it is possible to observe that the first three batches (B1, B2 and B3) did not present significant differences between them, but B4 and B5 were different the first batches and between themselves in relation to sugar consumption. It is also possible to notice the decrease in the percentage of sugar consumption with the increase in the number of batches.

The ethanol concentration produced (Table 2) for SBF with free cells did not show any significant difference between them. There was an increase in ethanol concentration from B1 to B2 $(13.76 \pm 1.34 \mathrm{~g} / \mathrm{L}$ and $21.59 \pm 1.34 \mathrm{~g} / \mathrm{L}$, respectively) in SBF for immobilized cells in MSC, however, the concentration reached levels close to B1 for cycles B3, B4 and B5. The best results were observed for SBF with cells that have already undergone at least one reuse in batches, similar to that reported by Lee et al. [25], who studied the production of E1G by S. cerevisiae cells immobilized in $2 \%(\mathrm{w} / \mathrm{v})$ calcium alginate. These authors reused the immobilized cells for five successive batches and compared the assay using free cells. They observed that among the five batches with immobilized cells, the best 
results were obtained in $\mathrm{B} 3$, which had a shorter fermentation time $(10 \mathrm{~h})$ and a $100 \%$ substrate-toproduct conversion factor the theory stoichiometry, 1.13 times greater than for free cells. Neitzel et al. [28] reported improved ethanol production and xylose specific uptake rate by $S$. passalidarum free cells in fermentations carried out during five repeated fed-batch fermentation with a medium simulating $\mathrm{HH}$ in sugars content and proportions.

By analyzing the results presented in Table 2, $\mathrm{Y}_{\mathrm{P} / \mathrm{S}}$ and $\mathrm{Q}_{\mathrm{P}}$ for SBF with free cells did not show a significant difference between batches, ranging from $0.30 \pm 0.06$ to $0.33 \pm 0.02 \mathrm{~g} / \mathrm{g}$ and $1.06 \pm 0.02$ to $1.16 \pm 0.22 \mathrm{~g} / \mathrm{L} . \mathrm{h}$, respectively. Yield also showed no significant difference and remained in the range of $58.07 \pm 3.70$ to $65.40 \pm 3.68 \%$ for these fermentations. Neitzel et al. [28] carried out successive fedbatch fermentation with free cells (initial cell concentration of $90 \mathrm{~g} / \mathrm{L}$ ) of $S$. passalidarum. They observed significant differences in kinetic parameters along fed-batches, and values for $\mathrm{Y}_{\mathrm{P} / \mathrm{S}}$ and $\mathrm{Q}_{\mathrm{P}}$ were 0.39 to $0.46 \mathrm{~g} / \mathrm{g} . \mathrm{L}$ and 1.29 to $1.79 \mathrm{~g} / \mathrm{L} . \mathrm{h}$ for first and fifth fed-batches, respectively [28]. In the present work, SBF with immobilized cells in MSC attained the highest $\mathrm{Y}_{\mathrm{P} / \mathrm{S}}$ and $\mathrm{Q}_{\mathrm{P}}$ in $\mathrm{B} 2,0.30 \pm 0.02 \mathrm{~g} / \mathrm{g}$ and $0.81 \pm 0.04 \mathrm{~g} / \mathrm{L} . \mathrm{h}$, significantly different from the values obtained in the other batches (Table 2 ). In relation to yield, B2 also presented the maximum value of this parameter, $59.28 \pm 4.21 \%$, and significantly different from the others. In the fermentation of coffee mucilage hydrolysate by $S$. cerevisiae cells immobilized in calcium alginate, Orrego et al. [26], using $50 \mathrm{~g} / \mathrm{L}$ of initial sugar concentration, obtained $0.33 \pm 0.01 \mathrm{~g} / \mathrm{g}$ and $0.94 \pm 0.07 \mathrm{~g} / \mathrm{L} . \mathrm{h}$ for conversion factor and productivity, respectively, values similar to those observed in the present work. Gajula et al. [40] used S. stipitis cells immobilized on sorghum stalks to produce bioethanol from peanut shell hydrolysate. When comparing the assays with free and immobilized cells, the best results for $\mathrm{Y}_{\mathrm{P} / \mathrm{S}}$, $\mathrm{Qp}$ and ethanol titer were obtained for the immobilized cells $(0.47 \mathrm{~g} / \mathrm{g}, 0.243 \mathrm{~g} / \mathrm{L} . \mathrm{h}$ and $20.45 \mathrm{~g} / \mathrm{L}$, respectively). In addition, Gajula et al. [40] did not observe any significant variation in the fermentation parameters until the fifth batch utilizing the reused cells.

The polymers used for cell immobilization can hinder the mass transfer of sugars and ethanol between the medium and the cells, creating microenvironments. This behavior limits the metabolic activity of yeast and decreases the production of the product of interest and $\mathrm{Y}_{\mathrm{P} / \mathrm{S}}$, when compared to systems with free cells [41], as observed in the present work. The concentration of polymers used for 
cell immobilization also influences sugar consumption, as observed by Lee et al. [25], who studied the immobilization of $S$. cerevisiae in calcium alginate in concentrations of 2 and $2.5 \%$. Ercan et al. [27] also evaluated the immobilization of $S$. cerevisiae in calcium alginate in concentrations of 2, 2.5 and $3 \%$. Both authors reported that the best results were obtained when the concentration of $2 \%$ alginate was used, the same concentration used in the present work. In this sense, the surface immobilization method (adsorption or covalent bonding to the support) presents an alternative to overcome these problems observed for immobilization with calcium alginate (wrapping/encapsulation method) for the production of E2G by S. passalidarum. Singh et al. [42], compared the performance of $S$. cerevisiae cells immobilized in calcium alginate and sugarcane bagasse. They observed better results for immobilization in bagasse (Y $/ \mathrm{S}$ of $0.44 \mathrm{~g} / \mathrm{g}$, Qp of $0.42 \mathrm{~g} / \mathrm{L} . \mathrm{h}$ and ethanol titer of $15.40 \mathrm{~g} / \mathrm{L}$ ). The authors also reported that bagasse allowed the use of the cells for ten cycles, without losses in parameters, while the alginate beads could be recycled for only four fermentations.

The production of xylitol for fermentations with free cells (data not shown) reached a maximum value in $\mathrm{B} 1(7.67 \pm 0.54 \mathrm{~g} / \mathrm{L})$. The production of this co-product decreased as the cells were reused in subsequent batches. This same behavior was observed for fermentation with immobilized cells in MSC, but reaching even lower xylitol concentrations, with the maximum value observed in B1 (3.24 $\pm 0.11 \mathrm{~g} / \mathrm{L})$. The concentration of both glycerol and acetic acid obtained was low for both conditions studied. The final concentration of glycerol obtained in fermentations with immobilized cells was approximately constant for batches, ranging from $0.24 \pm 0.01$ to $0.28 \pm 0.05 \mathrm{~g} / \mathrm{L}$. The concentration of acetic acid for fermentations with free cells reached its maximum value in B1 $(0.29 \pm 0.04 \mathrm{~g} / \mathrm{L})$. Glycerol is one of the by-products produced in the metabolism of glucose and xylose by $S$. passalidarum and is very important for obtaining various products in the cosmetics, drugs and food industries, among others. Yeasts produce glycerol from the reduction of dihydroxyacetone phosphate to glycerol-3-phosphate with the aid of the enzyme glycerol-3-phosphatase [23]. The production of glycerol associated with ethanol production was low compared to other literature reports [19, 43].

Fig. 3 shows specific xylose $\left(\mu_{\mathrm{Xyl}}\right)$ and glucose $\left(\mu_{\mathrm{Glu}}\right)$ uptake rates, and specific ethanol production rate $\left(\mu_{\mathrm{EtOH}}\right)$ for free and immobilized S. passalidarum cells fermented in MSC. For free cells (Fig. 3a), it was possible to observe the same behavior reported by Portugal-Nunes et al. [39], where 
$\mu_{\mathrm{Glu}}$ increased along with batch fermentations and it was higher than that observed for immobilized cells.

On the other hand, $\mu_{\mathrm{Xyl}}$ and $\mu_{\mathrm{EtOH}}$ did not show significant difference along with batches for SBF with free cells, probably due to discussion previously cited regarding $\mathrm{O}_{2}$ availability in shaker flasks fermentation, and reinforced by Neitzel et al. [28] work, where fed-batch fermentations were performed at appropriated $\mathrm{O}_{2}$ supply and an increasing in $\mu_{\mathrm{Xyl}}, \mu_{\mathrm{Glu}}$ and $\mu_{\mathrm{EtOH}}$ were observed along sequential fedbatches.

[Fig. 3]

Regarding $\mu_{\mathrm{Xyl}}, \mu_{\mathrm{Glu}}$ and $\mu_{\mathrm{EtOH}}$ for SBF with immobilized cells in MSC (Fig. 3b), few studies in the literature discuss these variables for cells entrapped in beads. However, due to the methodology applied in the present work it was possible to calculate these variables. In Fig. $3 \mathrm{~b}$ is possible to note a constant behavior of $\mu_{\mathrm{Xyl}}, \mu_{\mathrm{Glu}}$ and $\mu_{\mathrm{EtOH}}$ along SBF, proving the stability of the support along with fermentations.

\section{Immobilized S. passalidarum cells fermentetation in moderate and high initial sugars content}

Five consecutive batches (B1, B2, B3, B4 and B5) were performed in biological triplicate in a moderate (MSC) and a high (HSC) initial sugar concentration for E2G production. The comparison between the two sets of SBF with immobilized cells was performed from the analysis of the influence of the initial substrate concentration on the modified yield ( $\left.\mathrm{Y}_{\mathrm{P} / \mathrm{S}}\right)$ (Fig. 4a), residual sugar concentration (Fig. 4b), volumetric productivity ( $\left.Q_{P}\right)($ Fig. $4 c)$ and specific rate of xylose consumption $\left(\mu_{\mathrm{Xyl}}\right)$, in which the maximum values were considered (Fig. 4d), and the alginate bead structure (Fig. 5).

\section{[Figure 4]}

\section{[Figure 5]}

It is possible to observe that the ethanol production profile was similar in both tests. The sugar concentration influenced more clearly in B1 and B5, in which the concentration of ethanol obtained was quite different, obtaining respectively $35.5 \pm 0.01$ and $31.01 \pm 0.01 \mathrm{~g} / \mathrm{L}$ for HSC (Fig 1c) and $13.76 \pm$ 1.33 and $15.47 \pm 4.35 \mathrm{~g} / \mathrm{L}$ for MSC (Fig. $1 \mathrm{~b}$ ), however, in all batches the highest final concentration of ethanol was obtained in the test with the highest sugar concentration. 
between B1 and B2 was observed when comparing HSC and MSC. However, for B2, B3 and B4, all values achieved were higher for MSC. As before cited, Singh et al. [42] evaluated calcium alginate as immobilization support for S. cerevisiae and observed a decrease in the values of the parameters $\mathrm{Y}_{\mathrm{P} / \mathrm{S}}$ $\mathrm{Q}_{\mathrm{p}}$, ethanol title and conversion of sugars to ethanol along SBF in hydrolysate of microwave alkali pretreated sugarcane bagasse.

\section{[Table 3]}

For $\mathrm{Q}_{\mathrm{p}}$ (Fig. 4c and Table 3) all values were equal or statistically higher for HSC, when compared with MSC. Nikolic et al. [14] evaluated the influence of the initial concentration of glucose (98, 125, 150 and $176 \mathrm{~g} / \mathrm{L}$ ) in the fermentation with free cells. They observed that the highest concentration of bioethanol $(9 \% \mathrm{w} / \mathrm{w})$ was achieved in the highest initial sugar concentration. In both tests (MSC and HSC) the Qp values decreased when comparing the initial and final batches. The same behavior was observed by Singh et al. [42] in the use of S. cerevisiae cells immobilized in calcium alginate, in which $0.33 \mathrm{~g} / \mathrm{L} . \mathrm{h}$ was obtained in B1 and $0.27 \mathrm{~g} / \mathrm{L} . \mathrm{h}$ in B4.

Regarding the residual sugar concentration (Fig. 4b) in both MSC and HSC, there was an increase in concentration throughout the batches, with the values obtained in B5 approximately double that of B1. Higher residual sugar values were obtained for the HSC, in which for all batches, the values were at least 2.34 times higher than MSC. The highest ratio between values was obtained in B2 in which the residual sugar concentration of HSC was 5.18 times that of MSC. Maximum $\mu_{\text {xylose }}$ values were statistically equal or higher when compared to MSC (Table 3). MSC showed higher $\mu_{\text {xylose }}$ along SBF.

Some metabolites can have an inhibitory action on cells, depending on their concentration in the medium [13], including the carbon sources used. When the substrate is present in inhibitory levels, sugar consumption and product formation rates are decreased. Nikolic et al. [14] highlighted that high concentrations of the substrate can cause an osmotic shock of yeast cells and decrease heat and mass transfer. Thus, the lower $\mu_{\text {xylose }}$ and increased residual sugar concentration for HSC can be related to these factors. Nikolic et al. [14] evaluated the initial sugar concentrations of 150, 176 and $200 \mathrm{~g} / \mathrm{L}$ for immobilized cells of S. cerevisiae, and a decrease in the ethanol titer was observed for fermentation with $200 \mathrm{~g} / \mathrm{L}$, caused by substrate inhibition. Ozmihci and Kargi [44] evaluated the effect of substrate 
concentration (ranging between 52 and $312 \mathrm{~g} / \mathrm{L}$ ) on the production of bioethanol from cheese whey powder using free $K$. marxianus cells and observed a decrease in the consumption rate of sugar in concentrations above $75 \mathrm{~g} / \mathrm{L}$ of initial sugar concentration, due to substrate inhibition.

The limitations found for the production of ethanol in the fermentation with immobilized cells are probably related to the rate of the substrate and product transfer between medium and support, and to the capacity of sugar metabolization by the yeast. The specific ethanol production rate had small variation over time, which possibly shows that substrate diffused into the supports and had contact with cells were immediately consumed in both trials. The differences in parameters observed for MSC and HSC suggest that the increase in the residual substrate concentration may have occurred due to the greater imbalance between the medium and the interior of the support caused by the high concentration of sugar in the medium. An alternative to improving non-time-dependent parameters is increasing the fermentation time, since residual sugars were observed in both tests, with a higher concentration in the HSC. Another alternative would be a fed-batch regime as proposed by Nikolic et al. [14] and Ozmihci and Kargi [44], or a continuous fluidized bed reactor.

The morphology of the external and internal calcium alginate beads used in SBF is shown in Fig. 5. For the beads production, a concentration of $2 \%$ of calcium alginate, based on Ercan et al. [27], was used. The control samples (Fig. 5a, 5d and Fig. 5g, 5j for MSC and HSC, respectively) correspond to the fresh alginate beads, which contained $S$. passalidarum but that had not been used in any batch. There was a gel layer on the surface of the sphere that joins the yeast cells in both controls, forming a dense structure with few pores, as also observed by Malik et al. [45]. The internal section referring to the controls (Fig. 5d, Fig. 5j) showed that the cell immobilization was successful in the support, observing the cells involved by it along the bead. After three successive batches (Fig. 5b, Fig. 5h) and after five batches (Fig. 5c, Fig. 5i), it was possible to observe the beads' external images, an increase in the porosity of the material in both conditions studied. The deterioration of the beads can explain the increase in the concentration of free cells in the fermentation medium, as seen for both MSC (Fig. 2a) and HSC (Fig 2b), since the cells are naturally capable of transiting between the pores of the support [45]. With the increase of cells reutilization, the porosity also increases and more cells are desorbed. 
The evolution of $\mathrm{CO}_{2}$ can explain the occurrence of the observed detrition and increased

2 porosity during the fermentation process. The greater the production of ethanol, the greater the 3 production of $\mathrm{CO}_{2}$ by cellular metabolism, which needs to be eliminated. Thus, the transfer of gas

4 through the support may have contributed to the increased porosity. Apparently, the higher porosity did not facilitate mass transfer since no direct interference was observed between the increase in porosity and the pattern of sugar consumption and ethanol production. When comparing the two tests (MSC and HSC), there was no visible variation between the behavior of the porosity and the increase in the concentration of sugar concentration, in both cases the beads deterioration was similar with the batches and similar values of free cells concentrations were observed, for MSC (Fig. 2a) and HSC (Fig. 2b).

\section{CONCLUSION}

S. passalidarum was immobilized in calcium alginate for $\mathrm{E} 2 \mathrm{G}$ production in a medium simulating HH obtained from sugarcane bagasse in terms of sugar composition. The immobilization method with calcium alginate showed easy execution, good cost-benefit and viability for use with the studied yeast cells, generating an unprecedented response since immobilization studies for $S$. passalidarum are not described in the literature. The use of immobilized $S$. passalidarum for E2G production is promising since it was possible to reuse immobilized cells for 5 SBF. However, further study of the mass diffusion through the calcium alginate beads is necessary, in order to guarantee the ideal diffusion of substrate and $\mathrm{O}_{2}$ to favor the yeast metabolism. It is interesting to search for new supports that guarantee fermentation conditions, especially the $\mathrm{O}_{2}$ concentration, which is extremely necessary for xylose consumption by this yeast, therefore, continuous fluidized bed systems could be an alternative to assist in the transfer of this nutrient. Thereby, considering that research on immobilized cells for E2G is very limited, these findings may contribute to the lignocellulosic biomass fermentation industry.

Acknowledgments: This work was supported in part by grants and fellowships from FAPESC, CNPq (process number 308389/2019-0), CAPES (process number 88882.345331/2019-01), and FINEP 
1 (process $\mathrm{n}^{\circ}$ 01.09.0566.00/1421-08). We also acknowledge the Central Laboratory of Electron

2 Microscopy (LCME) from the Federal University of Santa Catarina (UFSC).

\section{Compliance with ethical standards}

4 Conflicts of Interest: The authors declare no conflict of interest.

5 Ethical approval: This article does not contain any studies with human participants or animals

6 performed by any of the authors.

7

8

\section{REFERENCES}

1. Mohd Azhar SH, Abdulla R, Jambo SA, Marbawi H, Gansau JA, Mohd Faik AA, Rodrigues KF (2017) Yeasts in sustainable bioethanol production: A review. Biochem Biophys Reports 10:52-61 . https://doi.org/10.1016/j.bbrep.2017.03.003

2. Karagoz P, Bill RM, Ozkan M (2019) Lignocellulosic ethanol production: Evaluation of new approaches, cell immobilization and reactor configurations. Renew Energy 143:741-752 . https://doi.org/10.1016/j.renene.2019.05.045

3. Robak K, Balcerek M (2020) Current state-of-the-art in ethanol production from lignocellulosic feedstocks. Microbiol Res 240:126534 . https://doi.org/10.1016/j.micres.2020.126534

4. Canilha L, Chandel AK, Suzane Dos Santos Milessi T, Antunes FAF, Luiz Da Costa Freitas W, Das Graças Almeida Felipe M, Da Silva SS (2012) Bioconversion of sugarcane biomass into ethanol: An overview about composition, pretreatment methods, detoxification of hydrolysates, enzymatic saccharification, and ethanol fermentation. J Biomed Biotechnol 2012:1-15 . https://doi.org/10.1155/2012/989572

5. Limayem A, Ricke SC (2012) Lignocellulosic biomass for bioethanol production: Current perspectives, potential issues and future prospects. Prog Energy Combust Sci 38:449-467 . https://doi.org/10.1016/j.pecs.2012.03.002

6. Modig T, Lidén G, Taherzadeh MJ (2002) Inhibition effects of furfural on alcohol dehydrogenase, aldehyde dehydrogenase and pyruvate dehydrogenase. Biochem J 363:769776 . https://doi.org/10.1042/0264-6021:3630769 
17 Mussatto SI, Roberto IC (2004) Alternatives for detoxification of diluted-acid lignocellulosic hydrolyzates for use in fermentative processes: A review. Bioresour Technol 93:1-10 . https://doi.org/10.1016/j.biortech.2003.10.005

8. Marton JM, Felipe MGA, Almeida e Silva JB, Pessoa A (2006) Evaluation of the activated charcoals and adsorption conditions used in the treatment of sugarcane bagasse hydrolysate for xylitol production. Brazilian J Chem Eng 23:9-21 . https://doi.org/10.1590/S010466322006000100002

9. Taherzadeh MJ, Karimi K (2011) Fermentation inhibitors in ethanol processes and different strategies to reduce their effects, 1st ed. Elsevier Inc.

10. Behera S, Ray RC (2015) Batch ethanol production from cassava ( Manihot esculenta Crantz .) flour using Saccharomyces cerevisiae cells immobilized in calcium alginate. 779-783 . https://doi.org/10.1007/s13213-014-0918-8

11. Rodríguez-Restrepo YA, Orrego CE (2020) Immobilization of enzymes and cells on lignocellulosic materials. Environ Chem Lett 18:787-806 . https://doi.org/10.1007/s10311-02000988-w

12. Lu J, Peng W, Lv Y, Jiang Y, Xu B, Zhang W, Zhou J, Dong W, Xin F, Jiang M (2020) Application of Cell Immobilization Technology in Microbial Cocultivation Systems for Biochemicals Production. Ind Eng Chem Res 59:17026-17034 . https://doi.org/10.1021/acs.iecr.0c01867

13. Schmidell W, Lima UA, Aquarone E, Borzani W (2001) Biotecnologia Industrial: Engenharia Bioquímica, 1st ed. Edgard Blucher LTDA, São Paulo

14. Nikolić S, Mojović L, Pejin D, Rakin M, Vukašinović M (2010) Production of bioethanol from corn meal hydrolyzates by free and immobilized cells of Saccharomyces cerevisiae var. ellipsoideus. Biomass and Bioenergy 34:1449-1456 . https://doi.org/10.1016/j.biombioe.2010.04.008

15. Zhu Y (2007) Immobilized Cell Fermentation for Production of Chemicals and Fuels. Elsevier B.V.

16. Mishra A, Sharma AK, Sharma S, Bagai R, Mathur AS, Gupta RP, Tuli DK (2016) 
Lignocellulosic ethanol production employing immobilized Saccharomyces cerevisiae in packed bed reactor. Renew Energy 98:57-63 . https://doi.org/10.1016/j.renene.2016.02.010

17. Pathania S, Sharma N, Handa S (2017) Immobilization of co-culture of Saccharomyces cerevisiae and Scheffersomyces stipitis in sodium alginate for bioethanol production using hydrolysate of apple pomace under separate hydrolysis and fermentation. Biocatal Biotransformation 35:450-459 . https://doi.org/10.1080/10242422.2017.1368497

18. Antunes FAF, Santos JC, Chandel AK, Carrier DJ, Peres GFD, Milessi TSS, da Silva SS (2019) Repeated batches as a feasible industrial process for hemicellulosic ethanol production from sugarcane bagasse by using immobilized yeast cells. Cellulose 26:3787-3800 . https://doi.org/10.1007/s10570-019-02341-z

19. Nakanishi SC, Soares LB, Biazi LE, Nascimento VM, Costa AC, Rocha GJM, Ienczak JL (2017) Fermentation strategy for second generation ethanol production from sugarcane bagasse hydrolyzate by Spathaspora passalidarum and Scheffersomyces stipitis. Biotechnol Bioeng 114:2211-2221 . https://doi.org/10.1002/bit.26357

20. Soares LB, Bonan CIDG, Biazi LE, Dionísio SR, Bonatelli ML, Andrade ALD, Renzano EC, Costa AC, Ienczak JL (2020) Investigation of hemicellulosic hydrolysate inhibitor resistance and fermentation strategies to overcome inhibition in non-saccharomyces species. Biomass and Bioenergy 137:105549 . https://doi.org/10.1016/j.biombioe.2020.105549

21. Selim KA, Easa SM, El-Diwany AI (2020) The xylose metabolizing yeast Spathaspora passalidarum is a promising genetic treasure for improving bioethanol production.

Fermentation 6:33 . https://doi.org/10.3390/FERMENTATION6010033

22. Rodrigues de Souza R de F, Dutra ED, Leite FCB, Cadete RM, Rosa CA, Stambuk BU, Stamford TLM, de Morais MA (2018) Production of ethanol fuel from enzyme-treated sugarcane bagasse hydrolysate using d-xylose-fermenting wild yeast isolated from Brazilian biomes. 3 Biotech 8:312 . https://doi.org/10.1007/s13205-018-1340-x

23. Martinez-Jimenez FD, Neitzel T, Biazi LE, Pereira IO, dos Santos LV, da Costa AC, Ienczak JL (2021) Exploiting the Non-conventional Yeast Spathaspora passalidarum as a Platform for Hemicellulosic Hydrolysate Conversion into Bioproducts: a Mini Review. Bioenergy Res. 
https://doi.org/10.1007/s12155-021-10257-5

24. Santos SC, de Sousa AS, Dionísio SR, Tramontina R, Ruller R, Squina FM, Vaz Rossell CE, da Costa AC, Ienczak JL (2016) Bioethanol production by recycled Scheffersomyces stipitis in sequential batch fermentations with high cell density using xylose and glucose mixture. Bioresour Technol 219:319-329 . https://doi.org/10.1016/j.biortech.2016.07.102

25. Lee KH, Choi IS, Kim YG, Yang DJ, Bae HJ (2011) Enhanced production of bioethanol and ultrastructural characteristics of reused Saccharomyces cerevisiae immobilized calcium alginate beads. Bioresour Technol 102:8191-8198 . https://doi.org/10.1016/j.biortech.2011.06.063

26. Orrego D, Zapata-Zapata AD, Kim D (2018) Ethanol production from coffee mucilage fermentation by S. cerevisiae immobilized in calcium-alginate beads. Bioresour Technol Reports 3:200-204 . https://doi.org/10.1016/j.biteb.2018.08.006

27. Ercan Y, Irfan T, Mustafa K (2013) Optimization of ethanol production from carob pod extract using immobilized Saccharomyces cerevisiae cells in a stirred tank bioreactor. Bioresour Technol 135:365-371 . https://doi.org/10.1016/j.biortech.2012.09.006

28. Neitzel T, Lima CS, Biazi LE, Collograi KC, Carvalho da Costa A, Vieira dos Santos L, Ienczak JL (2020) Impact of the Melle-Boinot process on the enhancement of secondgeneration ethanol production by Spathaspora passalidarum. Renew Energy 160:1206-1216 . https://doi.org/10.1016/j.renene.2020.07.027

29. Lima CS, Neitzel T, de Oliveira Pereira I, Rabelo SC, Ienczak JL, Roberto IC, Rocha GJM (2021) Effect of the Sugarcane Bagasse Deacetylation in the Pentoses Fermentation Process. Bioenergy Res. https://doi.org/10.1007/s12155-020-10243-3

30. Su YK, Willis LB, Jeffries TW (2015) Effects of aeration on growth, ethanol and polyol accumulation by Spathaspora passalidarum NRRL Y-27907 and Scheffersomyces stipitis NRRL Y-7124. Biotechnol Bioeng 112:457-469 . https://doi.org/10.1002/bit.25445

31. Puligundla P, Poludasu RM, Rai JK, Reddy Obulam VS (2011) Repeated batch ethanolic fermentation of very high gravity medium by immobilized Saccharomyces cerevisiae. Ann Microbiol 61:863-869 . https://doi.org/10.1007/s13213-011-0207-8 
32. Bonan CIDG, Tramontina R, dos Santos MW, Biazi LE, Soares LB, Pereira IO, Hoffmam ZB, Coutouné N, Squina FM, Robl D, Ienczak JL (2021) Biorefinery Platform for Spathaspora passalidarum NRRL Y-27907 in the Production of Ethanol, Xylitol, and Single Cell Protein from Sugarcane Bagasse. BioEnergy Res. https://doi.org/10.1007/s12155-021-10255-7

33. Berti F V., Srisuk P, Da Silva LP, Marques AP, Reis RL, Correlo VM (2017) Synthesis and characterization of electroactive Gellan gum spongy-like hydrogels for skeletal muscle tissue engineering applications. Tissue Eng - Part A 23:1-12 . https://doi.org/10.1089/ten.tea.2016.0430

34. Biazi LE, Martínez-Jimenez FD, Bonan CIDG, Soares LB, Morais ER, Ienczak JL, Costa AC (2020) A differential evolution approach to estimate parameters in a temperature-dependent kinetic model for second generation ethanol production under high cell density with Spathaspora passalidarum. Biochem Eng J 161:107586 . https://doi.org/10.1016/j.bej.2020.107586

35. Bonan CIDG, Biazi LE, Dionísio SR, Soares LB, Tramontina R, Sousa AS, de Oliveira Filho CA, Costa AC, Ienczak JL (2020) Redox potential as a key parameter for monitoring and optimization of xylose fermentation with yeast Spathaspora passalidarum under limited-oxygen conditions. Bioprocess Biosyst Eng 43:1509-1519 . https://doi.org/10.1007/s00449-020$02344-2$

36. Farias D, Maugeri-Filho F (2021) Sequential fed batch extractive fermentation for enhanced bioethanol production using recycled Spathaspora passalidarum and mixed sugar composition. Fuel 288:119673 . https://doi.org/10.1016/j.fuel.2020.119673

37. Ndubuisi IA, Qin Q, Liao G, Wang B, Moneke AN, Ogbonna JC, Jin C, Fang W (2020) Effects of various inhibitory substances and immobilization on ethanol production efficiency of a thermotolerant Pichia kudriavzevii. Biotechnol Biofuels 13:1-12 . https://doi.org/10.1186/s13068-020-01729-5

38. Agbogbo FK, Coward-Kelly G (2008) Cellulosic ethanol production using the naturally occurring xylose-fermenting yeast, Pichia stipitis. Biotechnol Lett 30:1515-1524 . https://doi.org/10.1007/s10529-008-9728-z 
39. Portugal-Nunes D, Nogué VSI, Pereira SR, Craveiro SC, Calado AJ, Xavier AMRB (2015) Effect of cell immobilization and PH on Scheffersomyces stipitis growth and fermentation capacity in rich and inhibitory media. Bioresour Bioprocess 2:1-9 . https://doi.org/10.1186/s40643-015-0042-z

40. Gajula C, Chandel AK, Konakalla R, Rudravaram R, Pogaku R, Mangamoori LN (2011) Fermentation of groundnut shell enzymatic hydrolysate for fuel ethanol production by free and sorghum stalks immobilized cells of Pichia stipitis NCIM 3498. Int J Chem React Eng 9:1-17 . https://doi.org/10.1515/1542-6580.2514

41. Nordmeier A, Chidambaram D (2018) Use of Zymomonas mobilis immobilized in doped calcium alginate threads for ethanol production. Energy 165:603-609 . https://doi.org/10.1016/j.energy.2018.09.137

42. Singh A, Sharma P, Saran AK, Singh N, Bishnoi NR (2013) Comparative study on ethanol production from pretreated sugarcane bagasse using immobilized Saccharomyces cerevisiae on various matrices. Renew Energy 50:488-493 . https://doi.org/10.1016/j.renene.2012.07.003

43. Cadete RM, Melo MA, Dussán KJ, Rodrigues RCLB, Silva SS, Zilli JE, Vital MJS, Gomes FCO, Lachance MA, Rosa CA (2012) Diversity and physiological characterization of Dxylose-fermenting yeasts isolated from the Brazilian Amazonian Forest. PLoS One 7:e43135 . https://doi.org/10.1371/journal.pone.0043135

44. Ozmihci S, Kargi F (2007) Kinetics of batch ethanol fermentation of cheese-whey powder (CWP) solution as function of substrate and yeast concentrations. Bioresour Technol 98:29782984 . https://doi.org/10.1016/j.biortech.2006.10.005

45. Malik K, Salama ES, El-Dalatony MM, Jalalah M, Harraz FA, Al-Assiri MS, Zheng Y, Sharma P, Li X (2021) Co-fermentation of immobilized yeasts boosted bioethanol production from pretreated cotton stalk lignocellulosic biomass: Long-term investigation. Ind Crops Prod 159:113122 . https://doi.org/10.1016/j.indcrop.2020.113122 
2 Fig. 1 - Profile of glucose, xylose, cells and ethanol concentrations over time for SBF with (a) free cells

4 sequential batches

5 Fig. 2 - Concentration of total cells, immobilized cells and cells suspended in the medium over the

\section{Figures Caption}

or (b) immobilized cells in MSC or (c) immobilized cells in HSC, where B1, B2, B3, B4 and B5 are the fermentation time for SBF with (a) immobilized cell in MSC or (b) immobilized cell in HSC, where B1, B2, B3, B4 e B5 are the sequential batches

Fig. 3 - Specific uptake rate of sugars (glucose and xylose) and specific ethanol production rate for SBF with (a) free cells and (b) immobilized cells, where B1, B2, B3, B4 and B5 are the sequential batches

Fig. 4 - Influence of the initial sugar concentration in (a) modified conversion factor ( $\left.\mathrm{Y}_{\mathrm{P} / \mathrm{S}}\right)$, (b) residual sugar concentration, (c) productivity (Qp) and (d) maximum specific xylose uptake rate $\left(\mu_{\text {xylose }}\right)$ for $S$. passalidarum immobilized in calcium alginate through SBF

Fig. 5 - Morphological analysis of the alginate beads before any batch (Control), after three batches (Batch 3) and after five batches (Batch 5), where (a) MSC control external surface, (b) MSC after batch 3 external surface, (c) MSC after batch 5 external surface, (d) MSC control internal surface, (e) MSC after batch 3 internal surface, (f) MSC after batch 5 internal surface, (g) HSC control external surface, (h) HSC after batch 3 external surface, (i) HSC after batch 5 external surface, (j) MSC control internal surface, (k) HSC after batch 3 internal surface, (l) HSC after batch 5 internal surface 
1 Table 1 - Xylose and glucose content for SBF with immobilized S. passalidarum cells in high sugars

2 content (HSC), medium sugars content (MSC) and for free S. passalidarum cells.

\section{HSC fermentations}

\begin{tabular}{ccc}
\hline Batches & Xylose $(\mathbf{g} / \mathbf{L})$ & Glucose $(\mathbf{g} / \mathbf{L})$ \\
\hline $\mathbf{1}$ & $94.27 \pm 4.88$ & $25.01 \pm 1.27$ \\
$\mathbf{2}$ & $92.93 \pm 8.11$ & $24.48 \pm 2.21$ \\
$\mathbf{3}$ & $90.67 \pm 0.30$ & $23.40 \pm 0.52$ \\
$\mathbf{4}$ & $96.21 \pm 1.57$ & $25.02 \pm 0.37$ \\
$\mathbf{5}$ & $96.54 \pm 5.86$ & $24.85 \pm 1.55$ \\
\hline
\end{tabular}

\section{MSC fermentations}

\begin{tabular}{ccc}
\hline Batches & Xylose $(\mathbf{g} / \mathbf{L})$ & Glucose $(\mathbf{g} / \mathbf{L})$ \\
\hline $\mathbf{1}$ & $56.87 \pm 2.49$ & $17.49 \pm 0.76$ \\
$\mathbf{2}$ & $57.20 \pm 2.07$ & $15.22 \pm 0.48$ \\
$\mathbf{3}$ & $56.82 \pm 3.68$ & $15.21 \pm 1.10$ \\
$\mathbf{4}$ & $56.52 \pm 4.43$ & $15.16 \pm 1.23$ \\
$\mathbf{5}$ & $56.95 \pm 1.18$ & $15.09 \pm 0.40$
\end{tabular}

Free cells fermentations

\begin{tabular}{ccc}
\hline Batches & Xylose $(\mathbf{g} / \mathbf{L})$ & Glucose $(\mathbf{g} / \mathbf{L})$ \\
\hline $\mathbf{1}$ & $78.25 \pm 1.53$ & $19.65 \pm 0.37$ \\
$\mathbf{2}$ & $71.22 \pm 1.58$ & $14.90 \pm 0.34$ \\
$\mathbf{3}$ & $69.24 \pm 0.30$ & $14.72 \pm 0.52$ \\
$\mathbf{4}$ & $70.05 \pm 0.01$ & $15.57 \pm 1.98$ \\
$\mathbf{5}$ & $69.01 \pm 2.90$ & $14.46 \pm 0.86$ \\
\hline
\end{tabular}

3

4 
1 Table 2 - Kinetic parameters of SBF with free and immobilized cells in MSC for E2G production by $S$.

2 passalidarum in a medium simulating $\mathrm{HH}$ sugar composition.

\section{Free cells fermentations}

\begin{tabular}{lccccc}
\hline Parameters/Batch & $\mathbf{1}$ & $\mathbf{2}$ & $\mathbf{3}$ & $\mathbf{4}$ & $\mathbf{5}$ \\
\hline Consumed sugar & $95.59 \pm 1.19^{\mathrm{Ab}}$ & $99.67 \pm$ & $99.76 \pm$ & $99.60 \pm$ & $98.33 \pm$ \\
$(\boldsymbol{\%})$ & $0.01^{\mathrm{Aa}}$ & $0.03^{\mathrm{Aa}}$ & $0.26^{\mathrm{Aa}}$ & $1.68^{\mathrm{Aab}}$ \\
& & $31.43 \pm$ & $29.82 \pm$ & $29.41 \pm$ & $30.41 \pm$ \\
$\mathbf{E t h a n o l ~ t i t e r ~ ( g / L ) ~}$ & $31.92 \pm 5.06^{\mathrm{Aa}}$ & $0.86^{\mathrm{Aa}}$ & $1.40^{\mathrm{Aa}}$ & $0.22^{\mathrm{Aa}}$ & $0.85^{\mathrm{Aa}}$ \\
$\mathbf{Y}_{\mathbf{P} / \mathbf{S}}(\mathbf{g} / \mathbf{g})^{* *}$ & $0.30 \pm 0.06^{\mathrm{Aa}}$ & $0.32 \pm 0.00^{\mathrm{Aa}}$ & $0.32 \pm 0.02^{\mathrm{Aa}}$ & $0.30 \pm 0.02^{\mathrm{Aa}}$ & $0.33 \pm 0.02^{\mathrm{Aa}}$ \\
$\mathbf{Q P}_{\mathbf{P}}(\mathbf{g} / \mathbf{L} . \mathbf{h}) * *$ & $1.16 \pm 0.22^{\mathrm{Aa}}$ & $1.14 \pm 0.02^{\mathrm{Aa}}$ & $1.12 \pm 0.06^{\mathrm{Aa}}$ & $1.06 \pm 0.02^{\mathrm{Aa}}$ & $1.14 \pm 0.03^{\mathrm{Aa}}$ \\
& $58.65 \pm$ & $62.49 \pm$ & $62.72 \pm$ & $58.07 \pm$ & $65.40 \pm$ \\
$\mathbf{\eta}_{\mathbf{E t O H}}(\boldsymbol{\%})$ & $11.30^{\mathrm{Aa}}$ & $0.02^{\mathrm{Aa}}$ & $4.34^{\mathrm{Aa}}$ & $3.70^{\mathrm{Aa}}$ & $3.68^{\mathrm{Aa}}$ \\
\hline
\end{tabular}

\section{MSC fermentations}

\begin{tabular}{|c|c|c|c|c|c|}
\hline Parameters/Batch & 1 & 2 & 3 & 4 & 5 \\
\hline $\begin{array}{l}\text { Sugar consumed } \\
(\%)\end{array}$ & $82.77 \pm 2.87^{\mathrm{Ba}}$ & $\begin{array}{l}89.34 \pm \\
2.32^{\mathrm{Ba}}\end{array}$ & $86.71 \pm 3.60^{\mathrm{Ba}}$ & $\begin{array}{l}70.78 \pm \\
1.29^{\mathrm{Bb}}\end{array}$ & $58.95 \pm 3.27^{\mathrm{Bc}}$ \\
\hline Ethanol titer (g/L) & $13.76 \pm 1.34^{\mathrm{Bb}}$ & $\begin{array}{c}21.59 \pm \\
1.34^{\mathrm{Ba}}\end{array}$ & $\begin{array}{l}18.54 \pm \\
0.85^{\mathrm{Bab}}\end{array}$ & $\begin{array}{l}16.06 \pm \\
1.89^{\mathrm{Bab}}\end{array}$ & $\begin{array}{l}15.47 \pm \\
4.35^{\mathrm{Bab}}\end{array}$ \\
\hline $\mathbf{Y}_{\mathbf{P} / \mathbf{S}}(\mathbf{g} / \mathbf{g})^{* *}$ & $0.22 \pm 0.04^{\mathrm{Ab}}$ & $0.30 \pm 0.02^{\mathrm{Aa}}$ & $0.25 \pm 0.02^{\mathrm{Bab}}$ & $0.26 \pm 0.02^{\text {Aab }}$ & $0.27 \pm 0.04^{\mathrm{Aab}}$ \\
\hline $\mathbf{Q}_{\mathbf{P}}(\mathrm{g} / \mathrm{L} \cdot \mathbf{h})^{* *}$ & $0.55 \pm 0.06^{\mathrm{Bb}}$ & $0.81 \pm 0.04^{\mathrm{Ba}}$ & $0.64 \pm 0.06^{\mathrm{Bab}}$ & $0.55 \pm 0.06^{\mathrm{Bb}}$ & $0.55 \pm 0.19^{\mathrm{Bab}}$ \\
\hline$\eta_{\text {EtOH }}(\%)$ & $42.31 \pm 7.18^{\mathrm{Ab}}$ & $\begin{array}{c}59.28 \pm \\
4.21^{\mathrm{Aa}}\end{array}$ & $\begin{array}{l}48.57 \pm \\
3.30^{\mathrm{Bab}}\end{array}$ & $\begin{array}{l}50.98 \pm \\
3.26^{\mathrm{Aab}}\end{array}$ & $\begin{array}{l}53.94 \pm \\
7.63^{\text {Aab }}\end{array}$ \\
\hline
\end{tabular}

* Different capital letters for the same parameter in the column statistically differentiate the tests with free cells and immobilized cells.

Different lowercase letters on the line statistically differentiate the batches of the same test.

Statistical differentiation was performed using the Tukey test $(\mathrm{p}<0.05)$.

** $\mathrm{Y}_{\mathrm{P} / \mathrm{S}}$ is the substrate to product conversion factor, $\mathrm{Qp}$ is the volumetric productivity and $\eta_{\mathrm{EtOH}}$ is the theoretical percentage yields 
Table 3 - Kinetic parameters of SBF with moderate concentration (MSC) and high sugar concentration

2 HSC) for E2G production by $S$. passalidarum in a medium simulating HH sugar composition.

\section{MSC fermentations}

\begin{tabular}{lccccc}
\hline Parameters/batch & $\mathbf{1}$ & $\mathbf{2}$ & $\mathbf{3}$ & $\mathbf{4}$ & $\mathbf{5}$ \\
\hline Residual sugar & $12.76 \pm$ & $7.75 \pm 1.85^{\mathrm{Ac}}$ & $9.68 \pm 3.32^{\mathrm{Ac}}$ & $20.98 \pm$ & $29.54 \pm$ \\
$(\mathbf{g} / \mathbf{L})$ & $1.66^{\mathrm{Ac}}$ & & & $2.42^{\mathrm{Ab}}$ & $1.77^{\mathrm{Aa}}$ \\
$\mathbf{Y}^{\prime} \mathbf{P} / \mathbf{S}(\mathbf{g} / \mathbf{g})^{* *}$ & $0.18 \pm 0.02^{\mathrm{Ab}}$ & $0.27 \pm 0.02^{\mathrm{Aa}}$ & $0.21 \pm 0.01^{\mathrm{Aab}}$ & $0.18 \pm 0.01^{\mathrm{Ab}}$ & $0.18 \pm 0.06^{\mathrm{Ab}}$ \\
$\mathbf{Q}_{\mathbf{P}}(\mathbf{g} / \mathbf{L} \cdot \mathbf{h})^{* *}$ & $0.55 \pm 0.06^{\mathrm{Bb}}$ & $0.81 \pm 0.04^{\mathrm{Ba}}$ & $0.64 \pm 0.06^{\mathrm{Aab}}$ & $0.55 \pm 0.06^{\mathrm{Bb}}$ & $0.55 \pm 0.19^{\mathrm{Aab}}$ \\
$\boldsymbol{\mu}_{\mathbf{x y l}}(\mathbf{g} / \mathbf{g} \cdot \mathbf{h})^{* *}$ & $0.14 \pm 0.01^{\mathrm{Aa}}$ & $0.14 \pm 0.01^{\mathrm{Aa}}$ & $0.14 \pm 0.01^{\mathrm{Aa}}$ & $0.11 \pm 0.02^{\mathrm{Aab}}$ & $0.07 \pm 0.04^{\mathrm{Ab}}$
\end{tabular}

\section{HSC fermentations}

\begin{tabular}{lccccc}
\hline Parameters/batch & $\mathbf{1}$ & $\mathbf{2}$ & $\mathbf{3}$ & $\mathbf{4}$ & $\mathbf{5}$ \\
\hline Residual sugar & $35.69 \pm$ & $40.19 \pm$ & $48.15 \pm$ & $55.04 \pm$ & $69.22 \pm$ \\
$(\mathbf{g} / \mathbf{L})$ & $0.96^{\mathrm{Bd}}$ & $2.78^{\mathrm{Bcd}}$ & $3.33^{\mathrm{Bbc}}$ & $0.88^{\mathrm{Bb}}$ & $8.61^{\mathrm{Ba}}$ \\
$\mathbf{Y}_{\mathbf{P} / \mathbf{S}}^{\prime}(\mathbf{g} / \mathbf{g})^{* *}$ & $0.18 \pm 0.02^{\mathrm{Aa}}$ & $0.19 \pm 0.03^{\mathrm{Ba}}$ & $0.16 \pm 0.02^{\mathrm{Bab}}$ & $0.13 \pm 0.01^{\mathrm{Bb}}$ & $0.13 \pm 0.02^{\mathrm{Ab}}$ \\
$\mathbf{Q}_{\mathbf{P}}(\mathbf{g} / \mathbf{L} . \mathbf{h})^{* *}$ & $0.92 \pm 0.03^{\mathrm{Aab}}$ & $0.93 \pm 0.04^{\mathrm{Aa}}$ & $0.76 \pm 0.10^{\mathrm{Abc}}$ & $0.67 \pm 0.03^{\mathrm{Ac}}$ & $0.65 \pm 0.07^{\mathrm{Ac}}$ \\
$\boldsymbol{\mu}_{\mathbf{x y l}}(\mathbf{g} / \mathbf{g} . \mathbf{h})^{* *}$ & $0.11 \pm 0.01^{\mathrm{Ba}}$ & $0.10 \pm 0.02^{\mathrm{Ba}}$ & $0.12 \pm 0.01^{\mathrm{Aa}}$ & $0.10 \pm 0.01^{\mathrm{Aa}}$ & $0.05 \pm 0.02^{\mathrm{Ab}}$
\end{tabular}

\footnotetext{
* Different capital letters for the same parameter in the column statistically differentiate the tests with free cells and immobilized cells.

Different lowercase letters on the line statistically differentiate the batches of the same test.

Statistical differentiation was performed using the Tukey test $(\mathrm{p}<0.05)$.

** $\mathrm{Y}_{\mathrm{P} / \mathrm{S}}$ is the substrate to product conversion factor, $\mathrm{Qp}$ is the volumetric productivity and $\mu_{\mathrm{xyl}}$ is the maximum xylose consumption rate
} 
Fig. 1

(a)

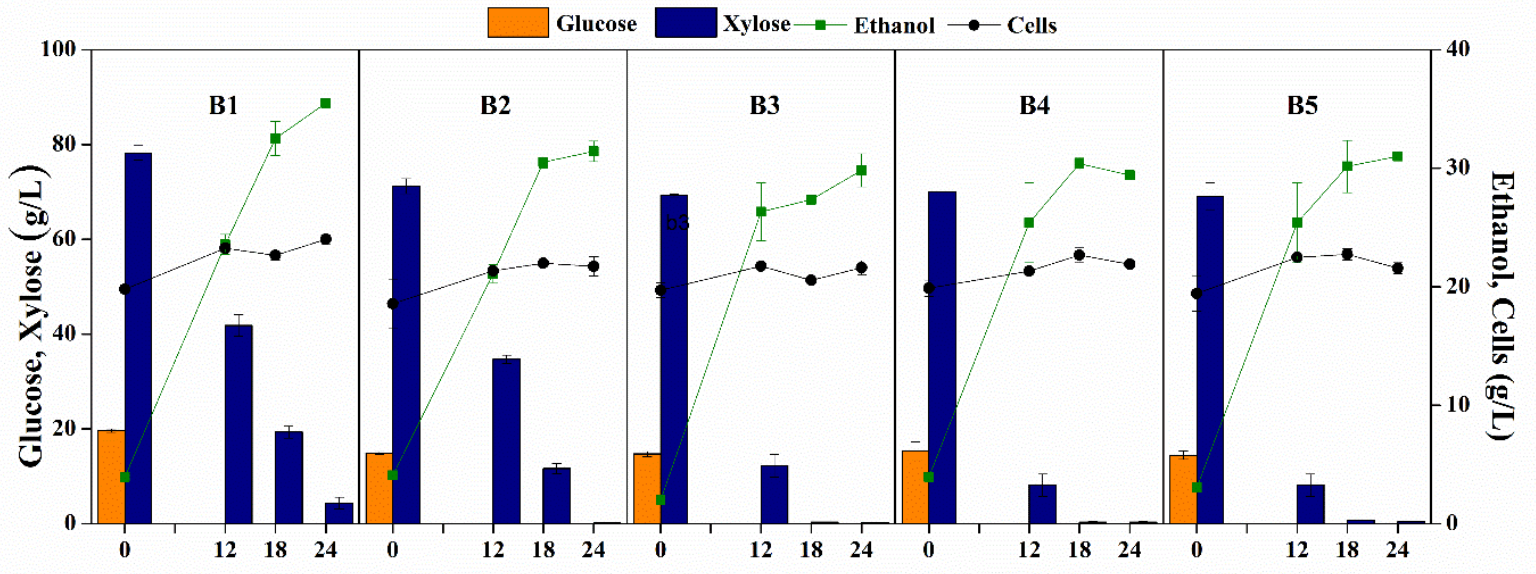

(b)

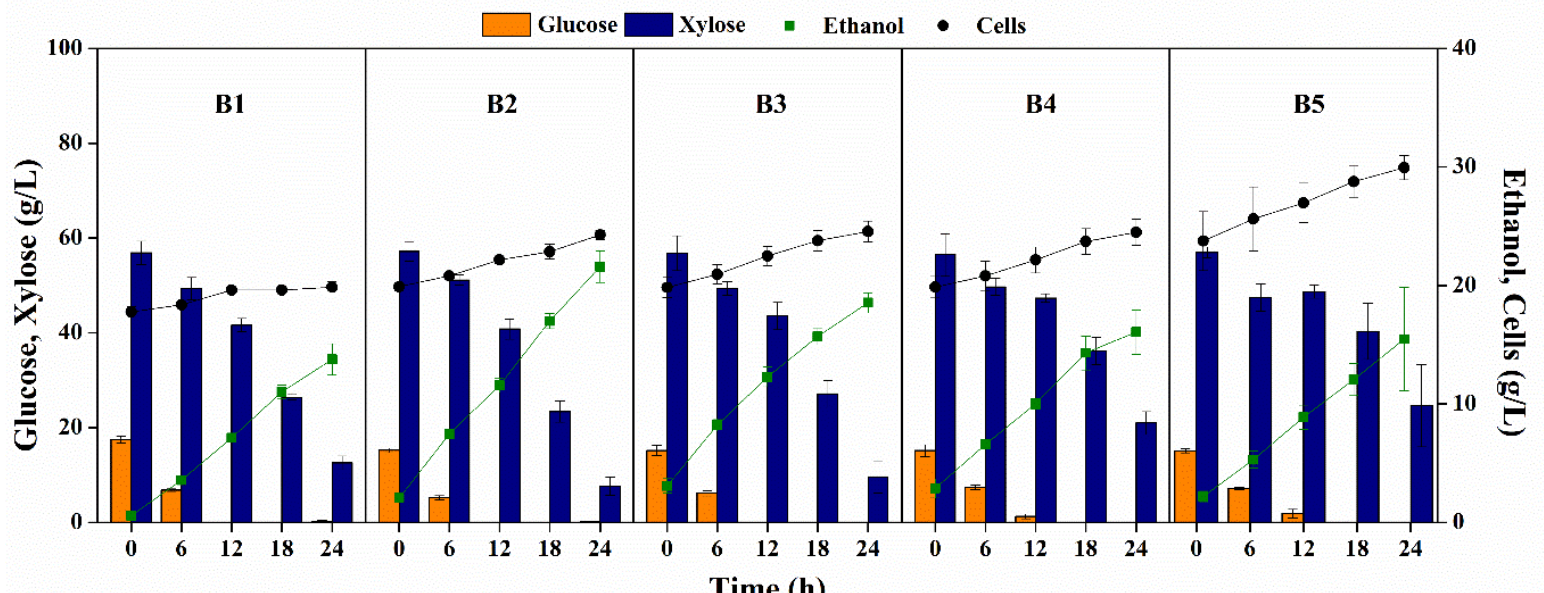

(c)

Time (h)

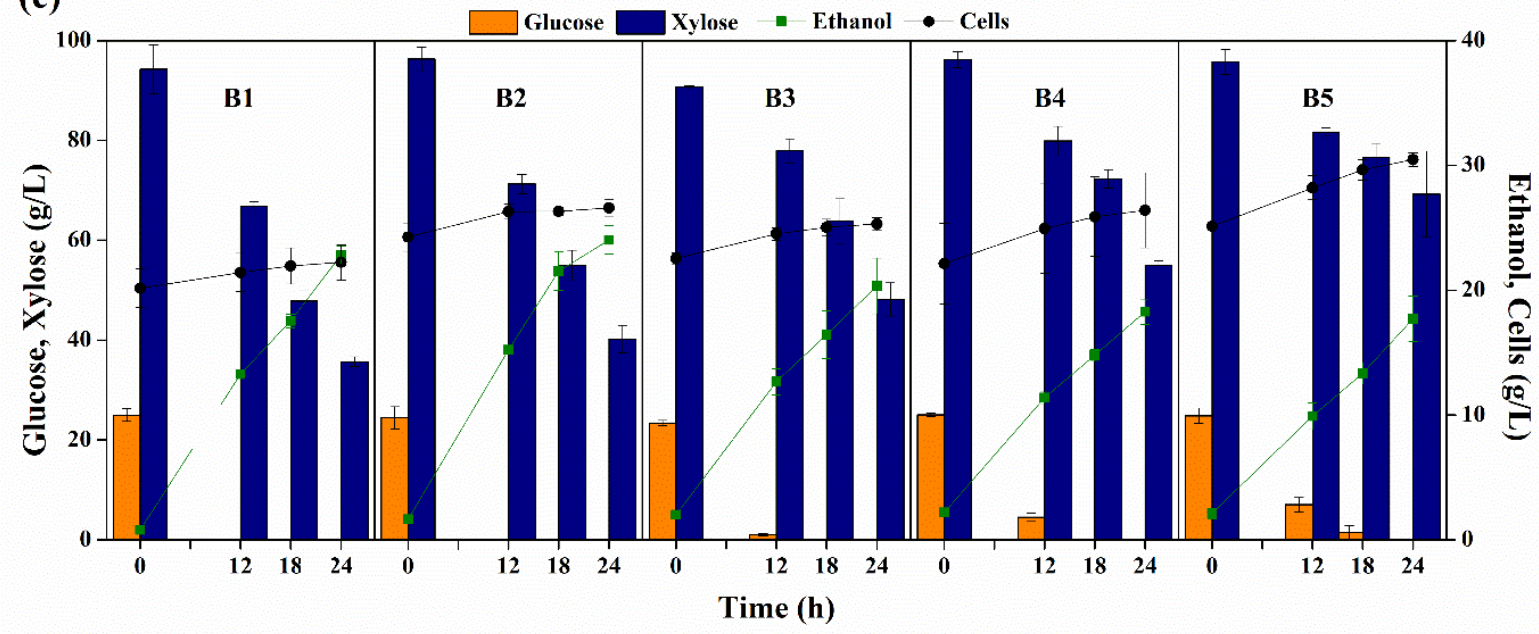


Fig. 2

(a)

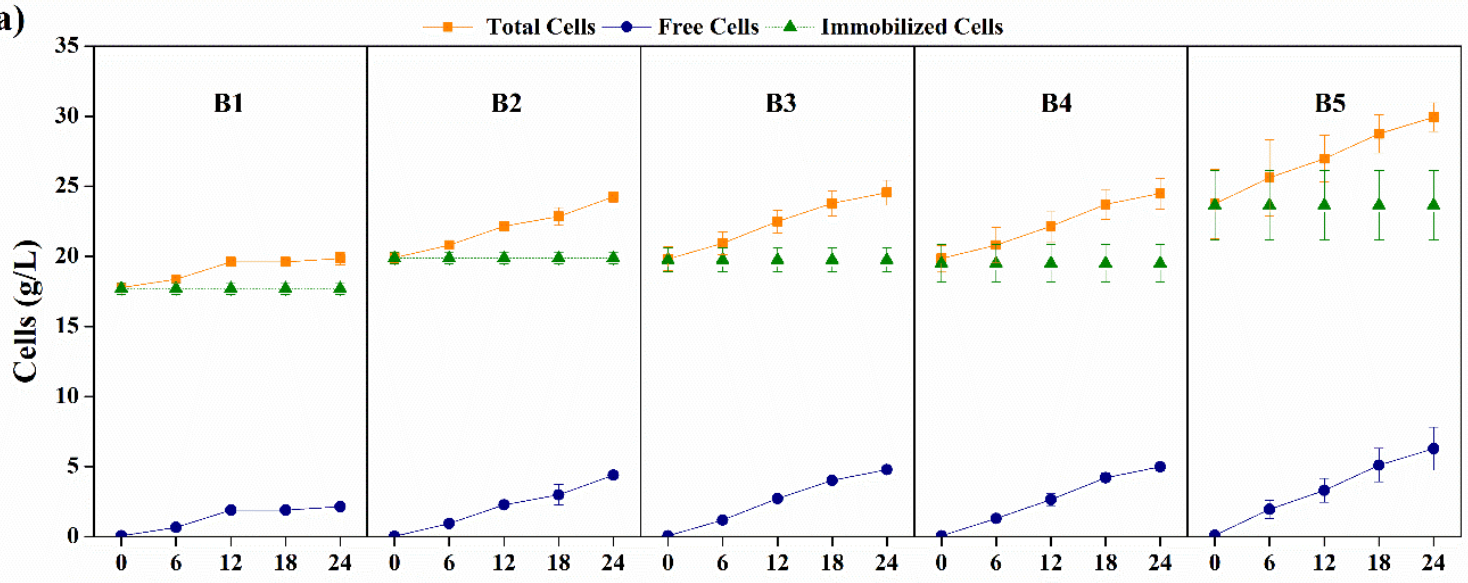

Time (h)

(b)

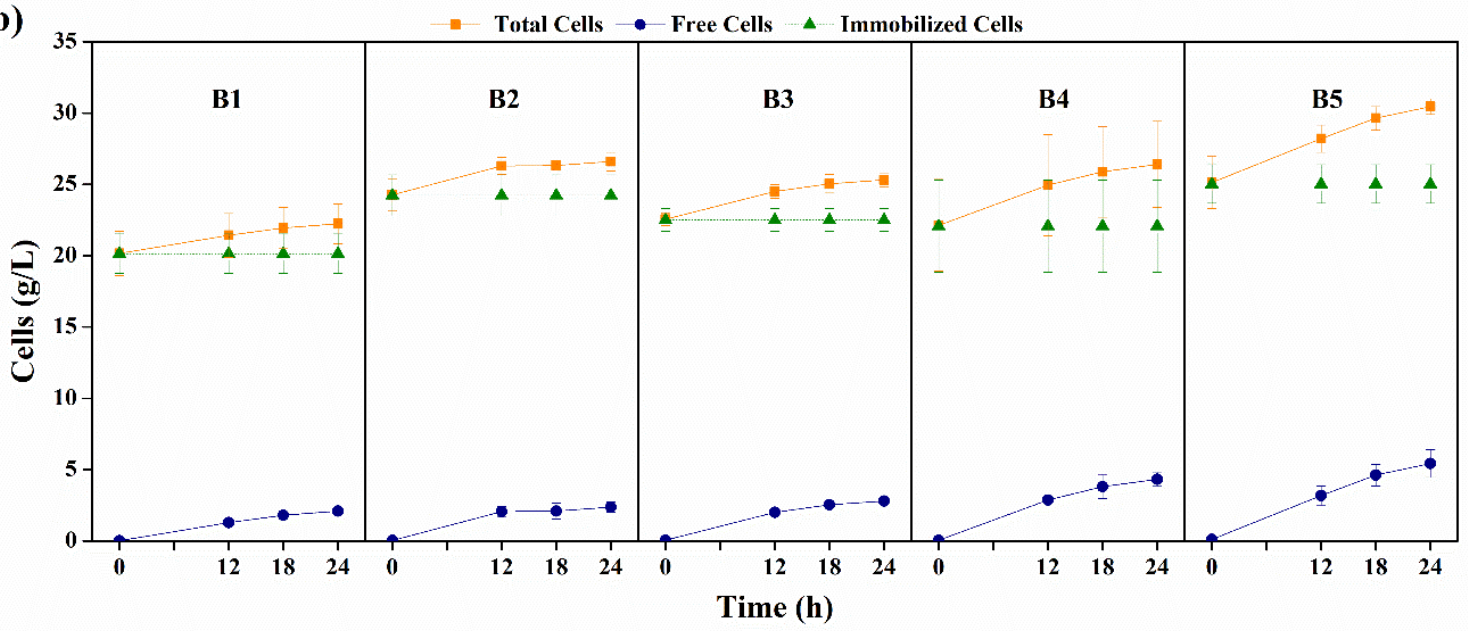


Fig. 3

(a)

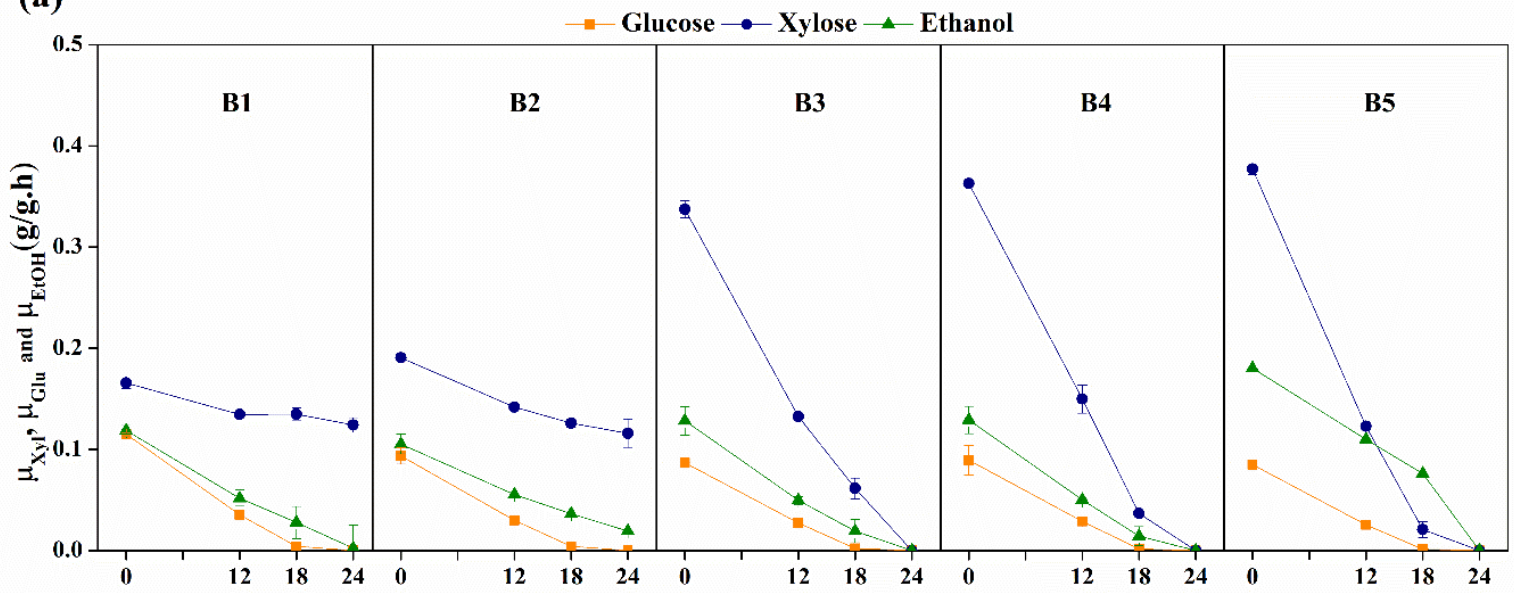

(b)

Time (h)

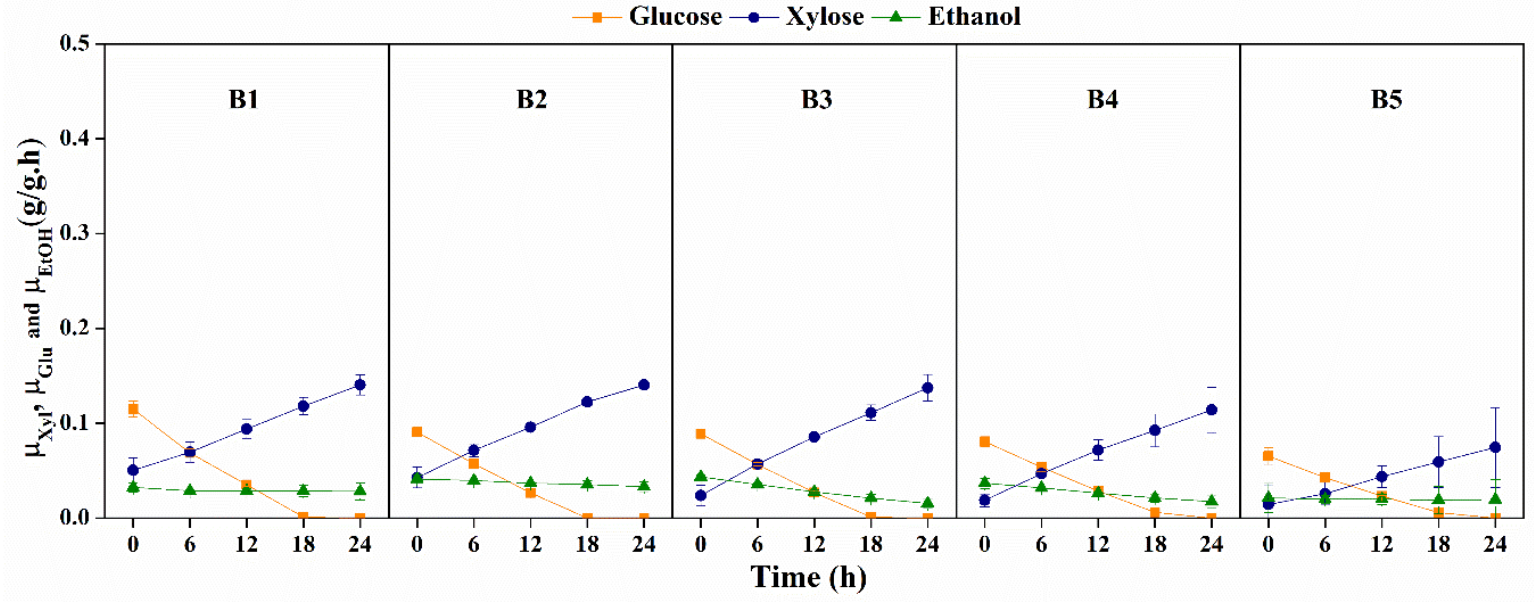

2

3 
Fig. 4

(a)

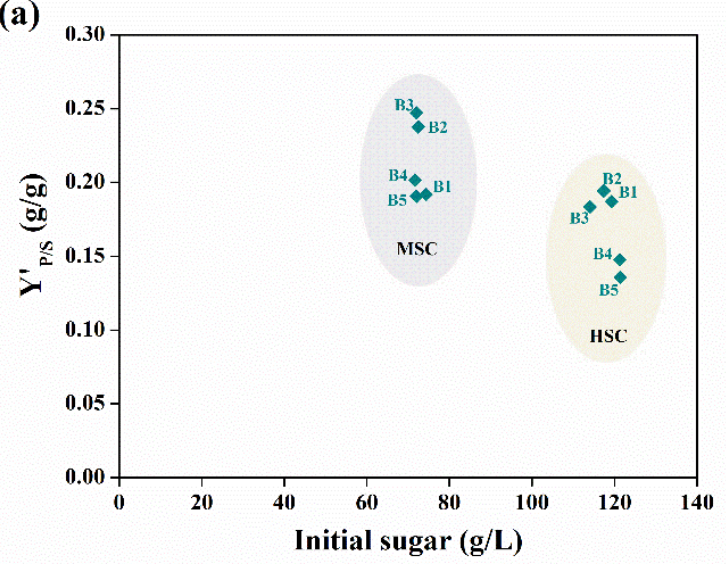

(c)

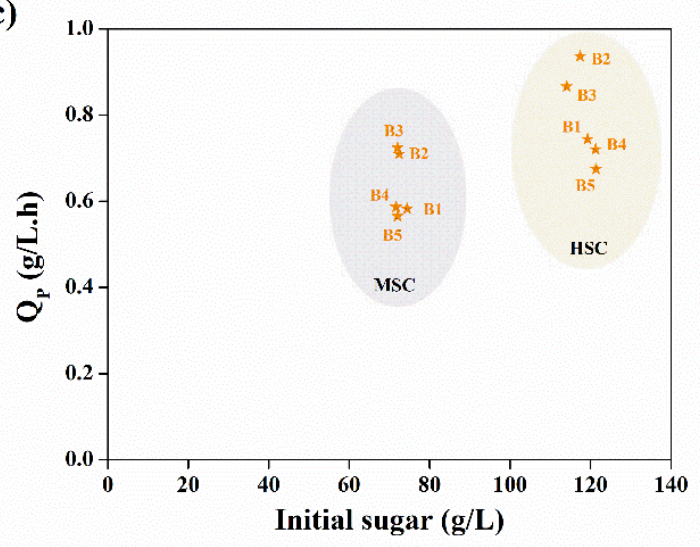

(b)

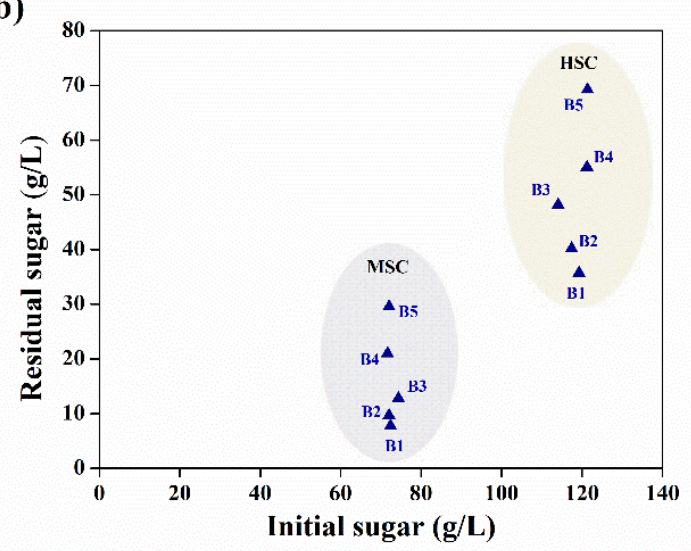

(d)

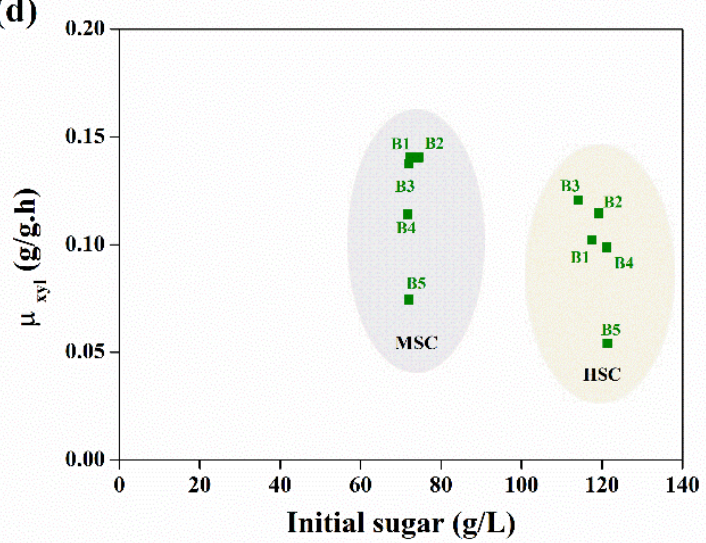


Fig. 5

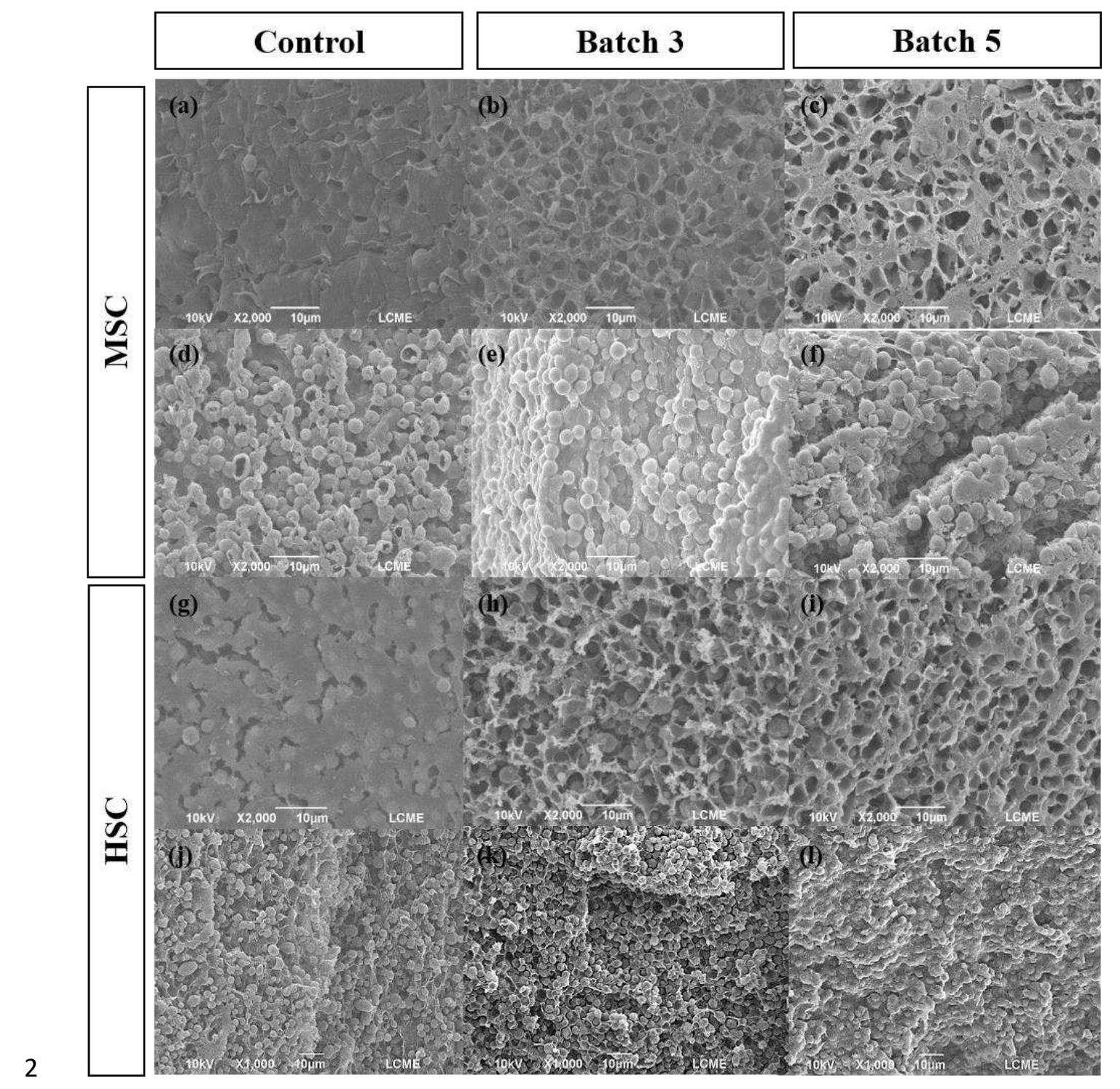

3 
Figures

(a)

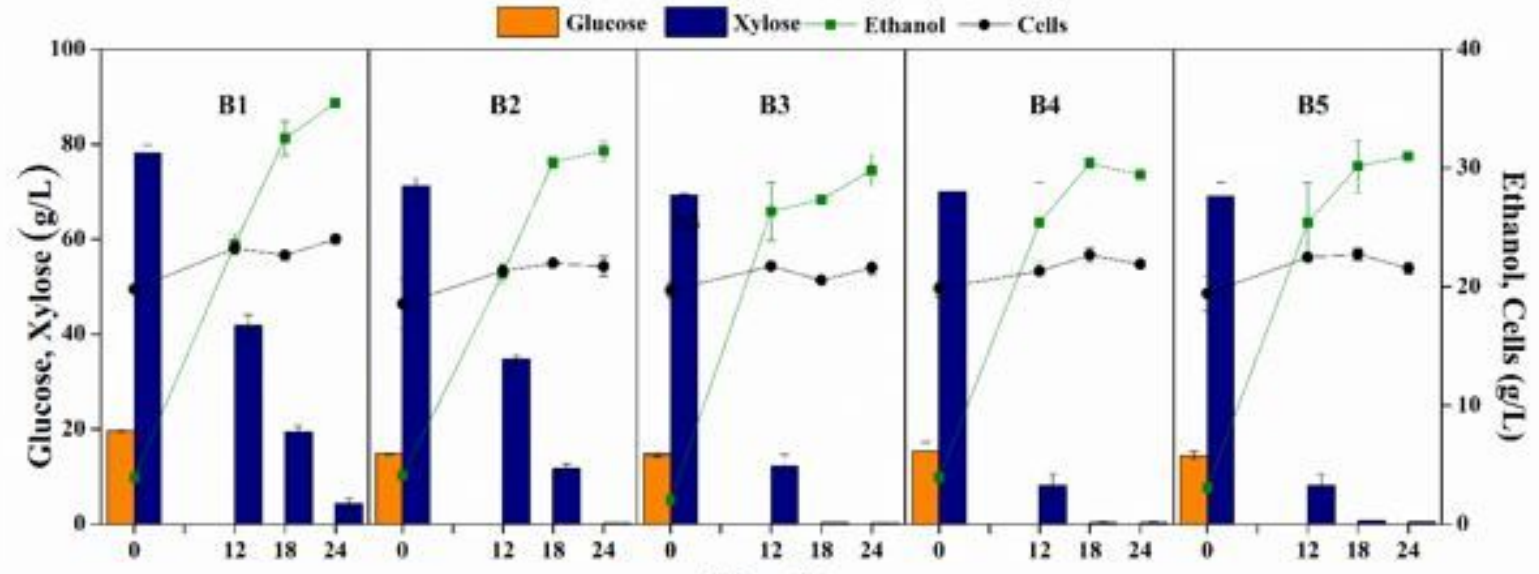

(b)

Time (h)

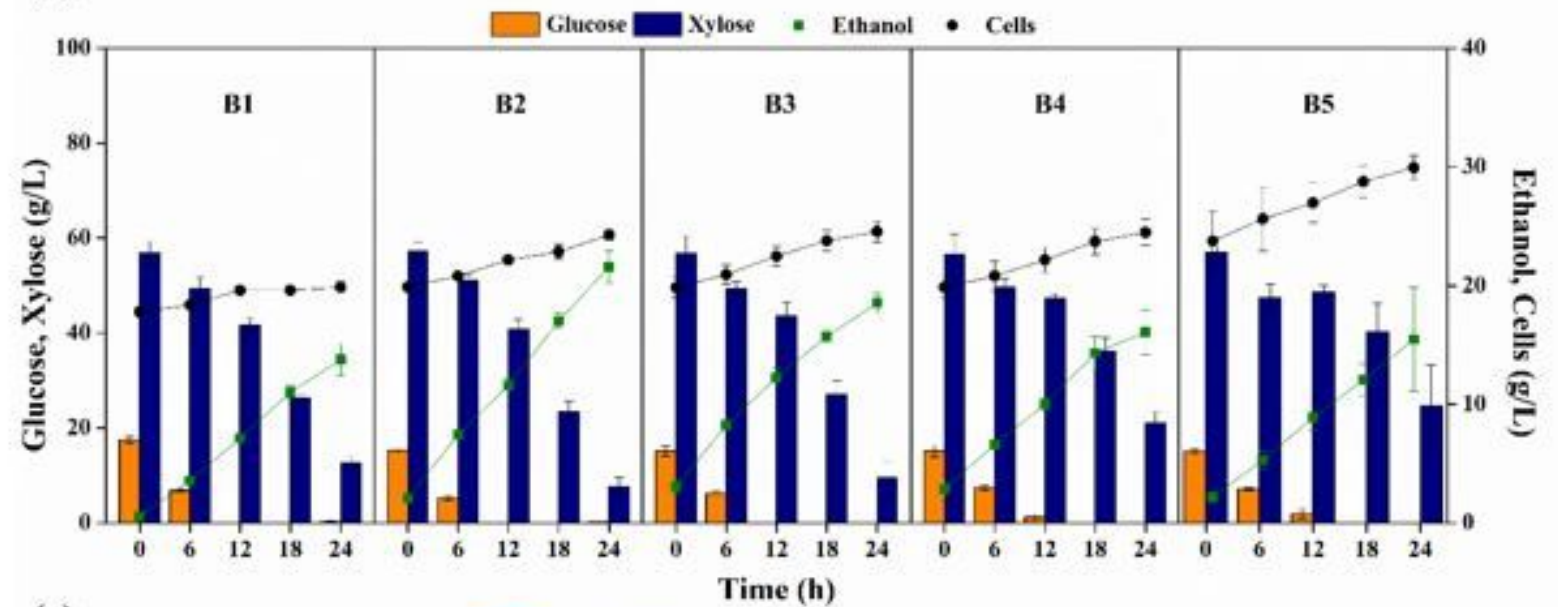

(c)

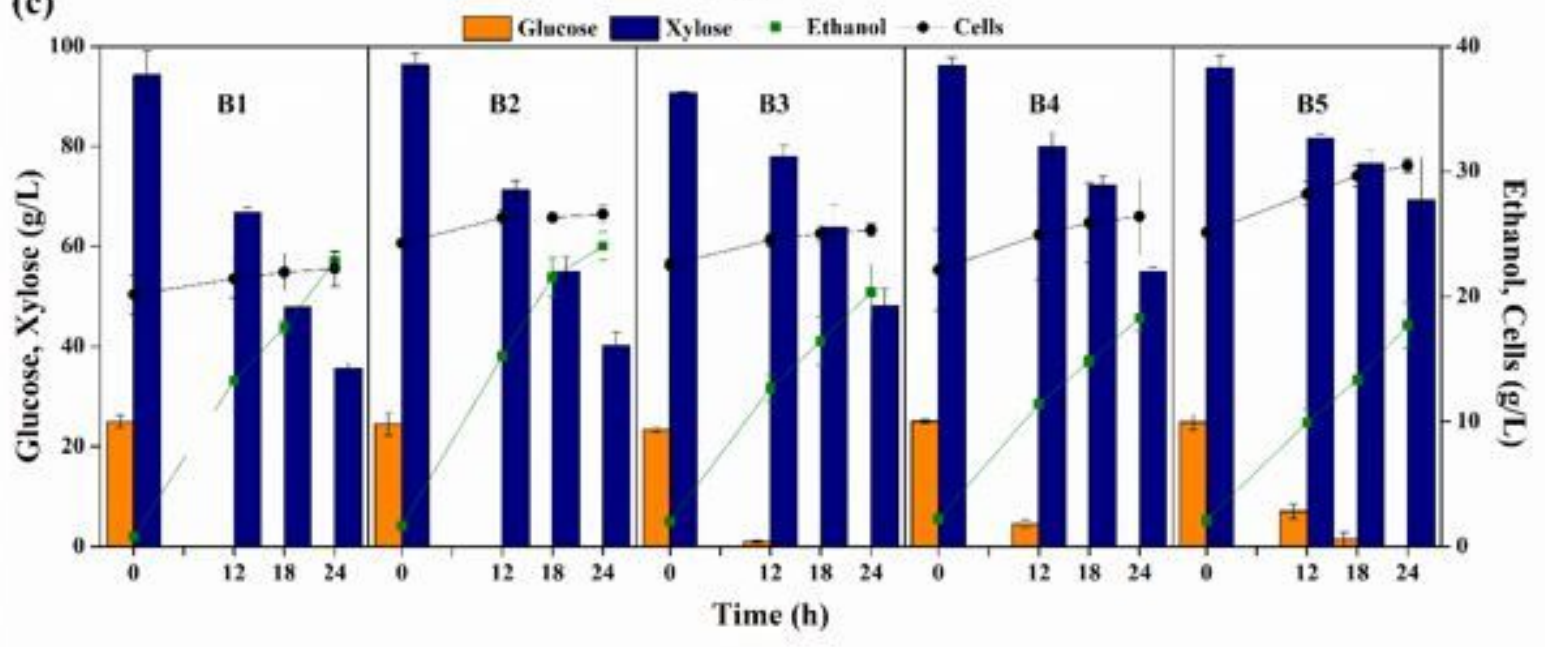

Figure 1

Profile of glucose, xylose, cells and ethanol concentrations over time for SBF with (a) free cells or (b) immobilized cells in MSC or (c) immobilized cells in HSC, where B1, B2, B3, B4 and B5 are the sequential batches 
(a)

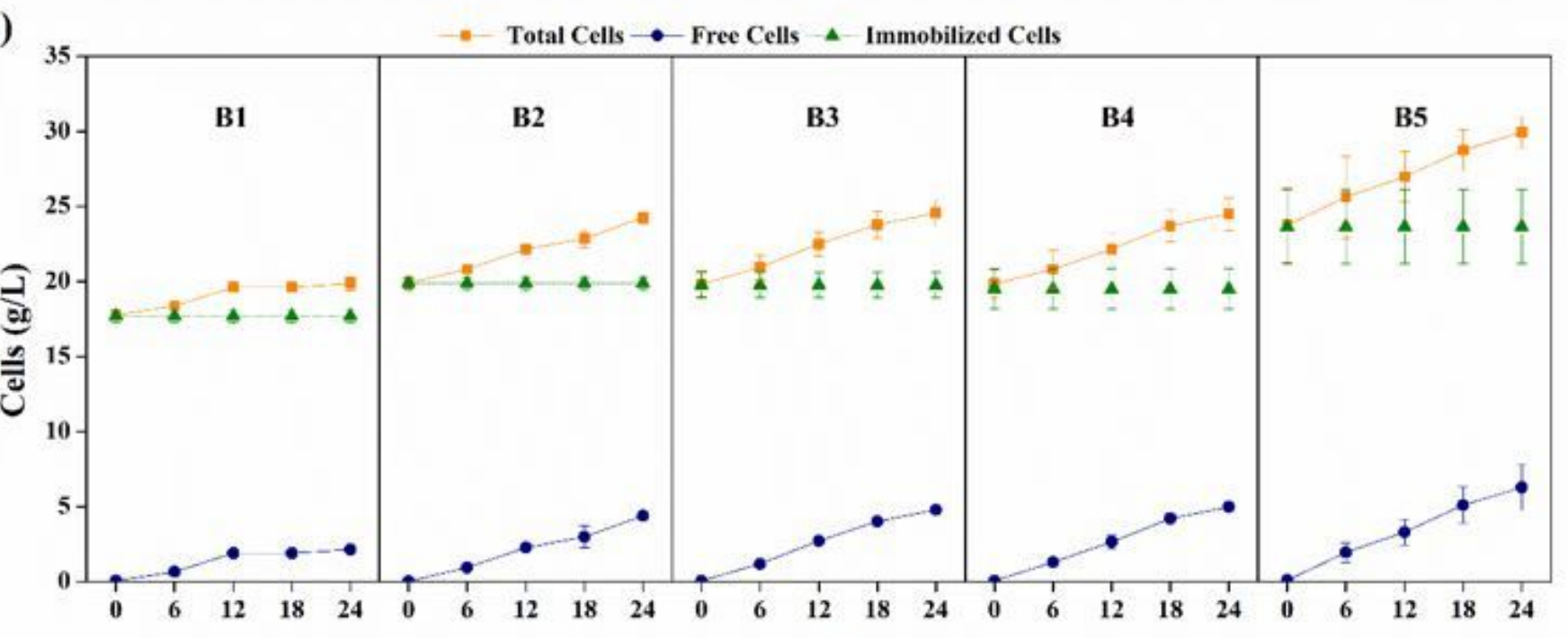

Time (h)

(b)

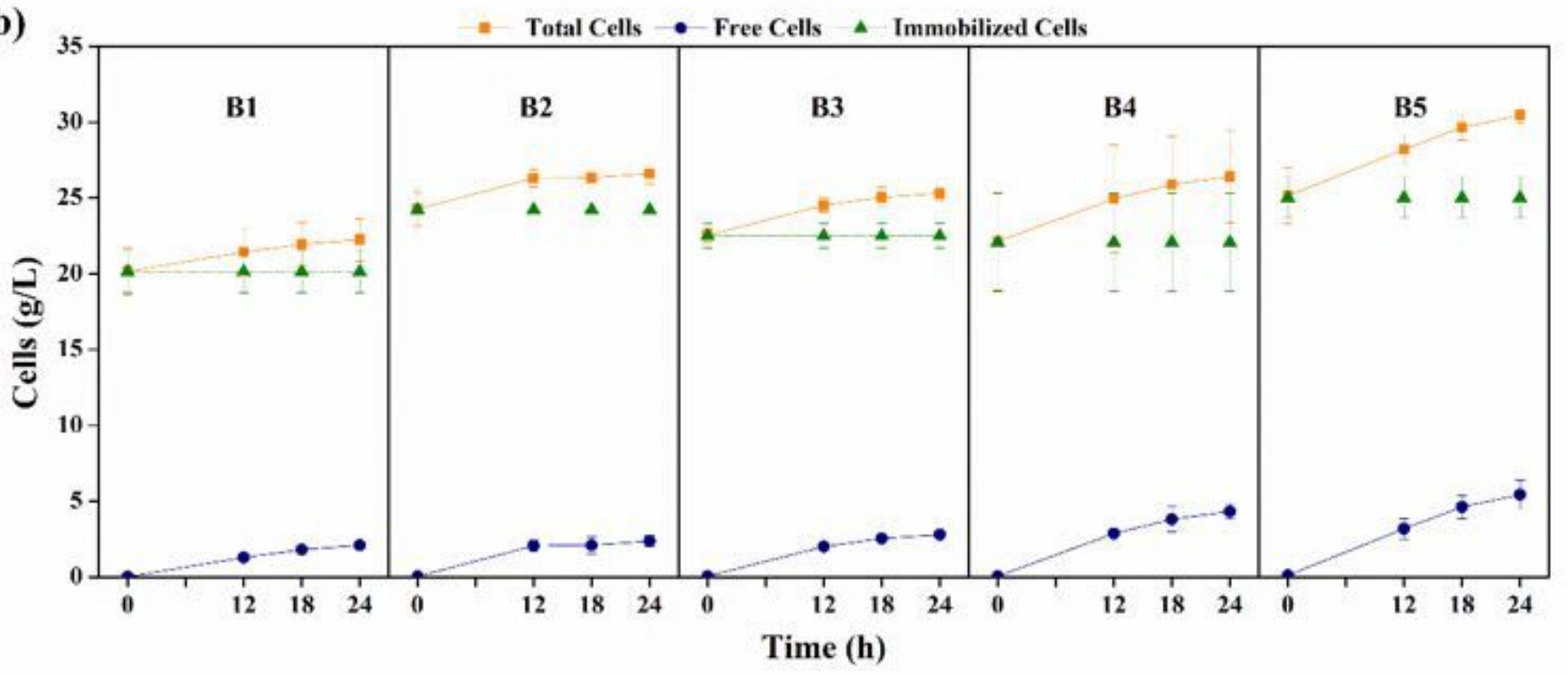

Figure 2

Concentration of total cells, immobilized cells and cells suspended in the medium over the fermentation time for SBF with (a) immobilized cell in MSC or (b) immobilized cell in HSC, where B1, B2, B3, B4 e B5 are the sequential batches 
(a)

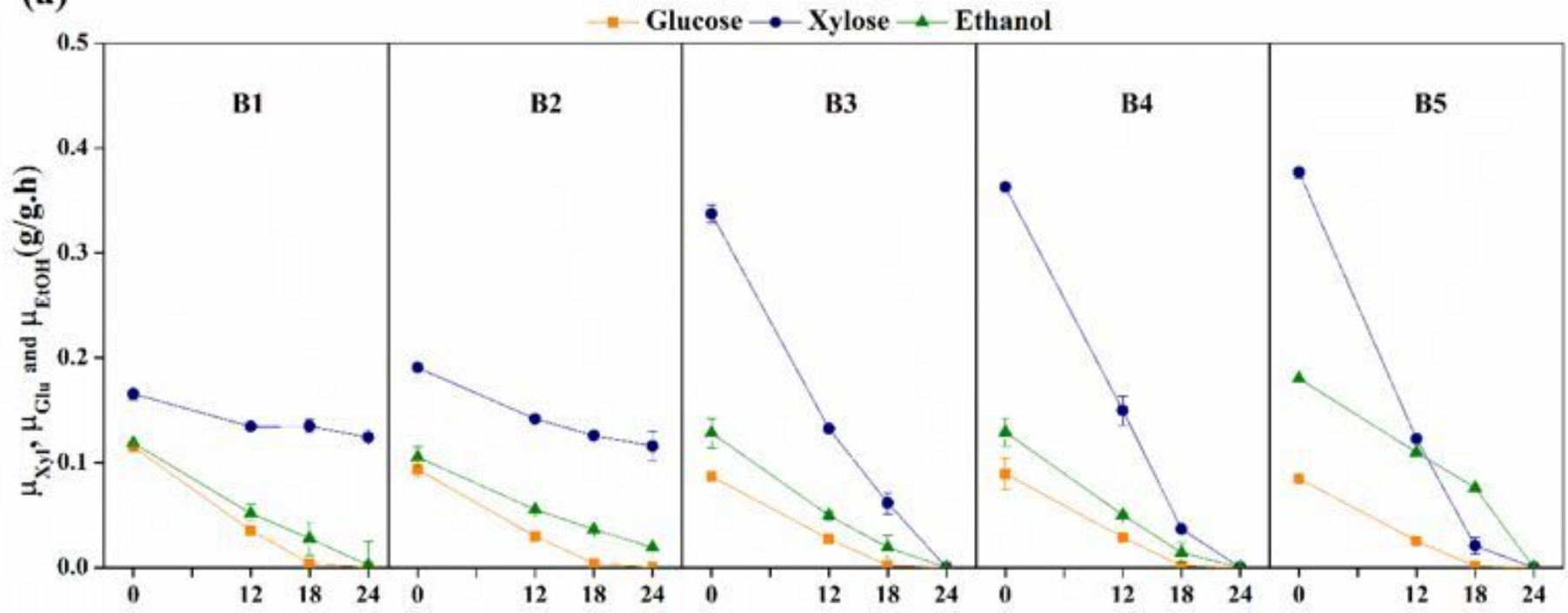

(b)

Time (h)

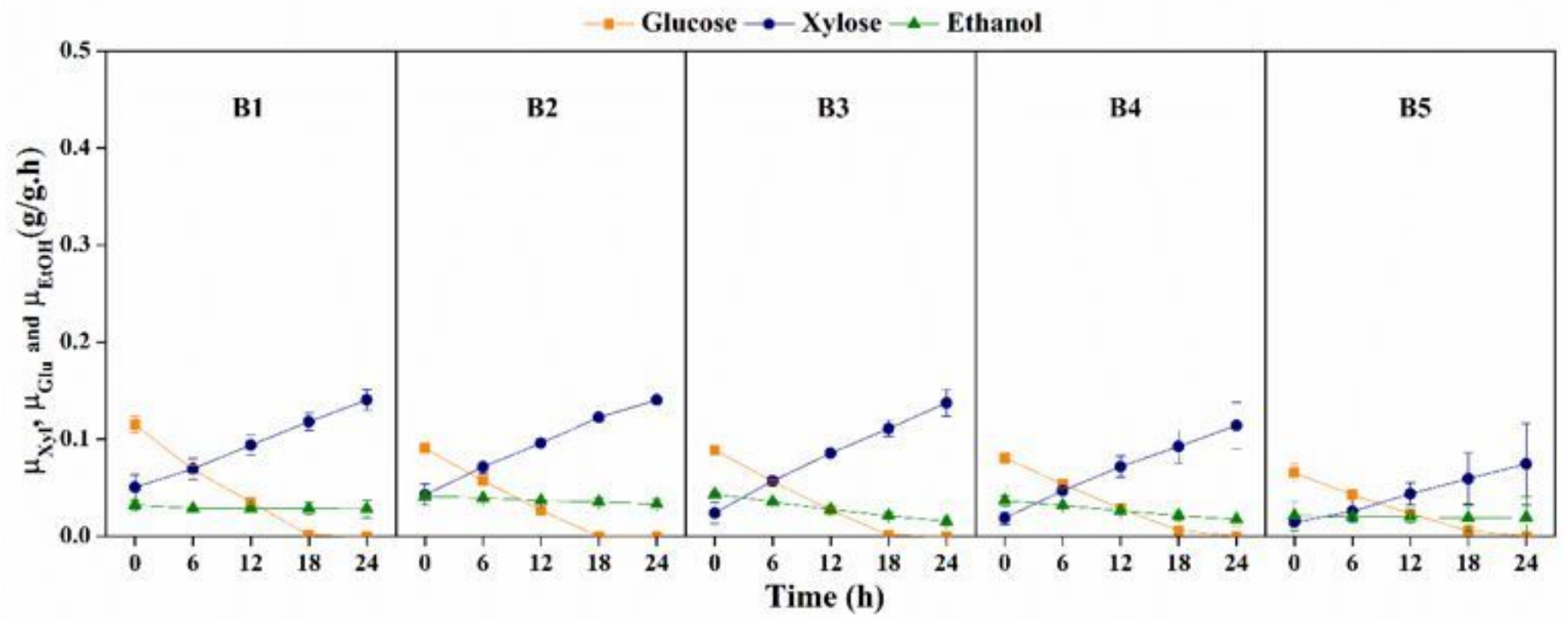

Figure 3

Specific uptake rate of sugars (glucose and xylose) and specific ethanol production rate for SBF with (a) free cells and (b) immobilized cells, where B1, B2, B3, B4 and B5 are the sequential batches 
(a)

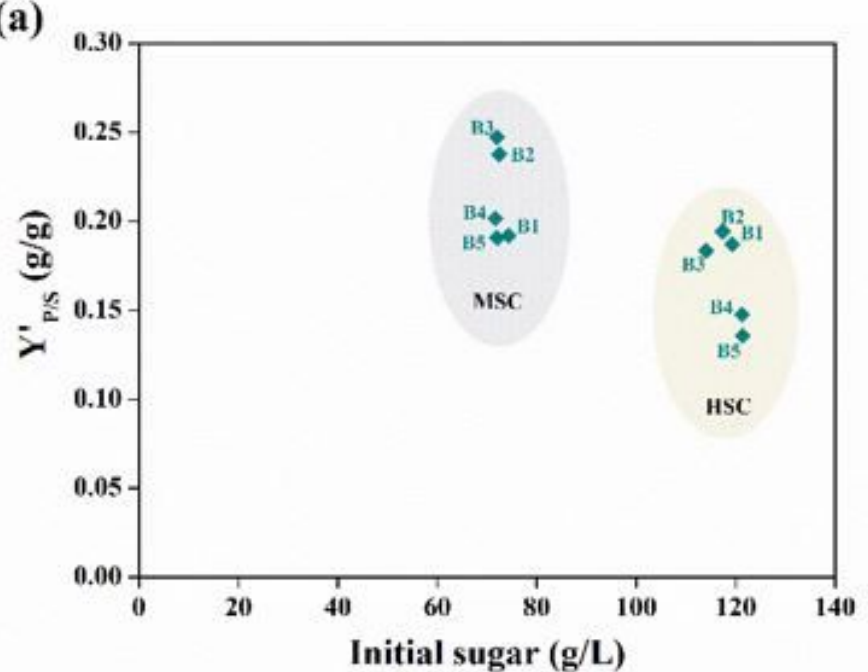

(c)

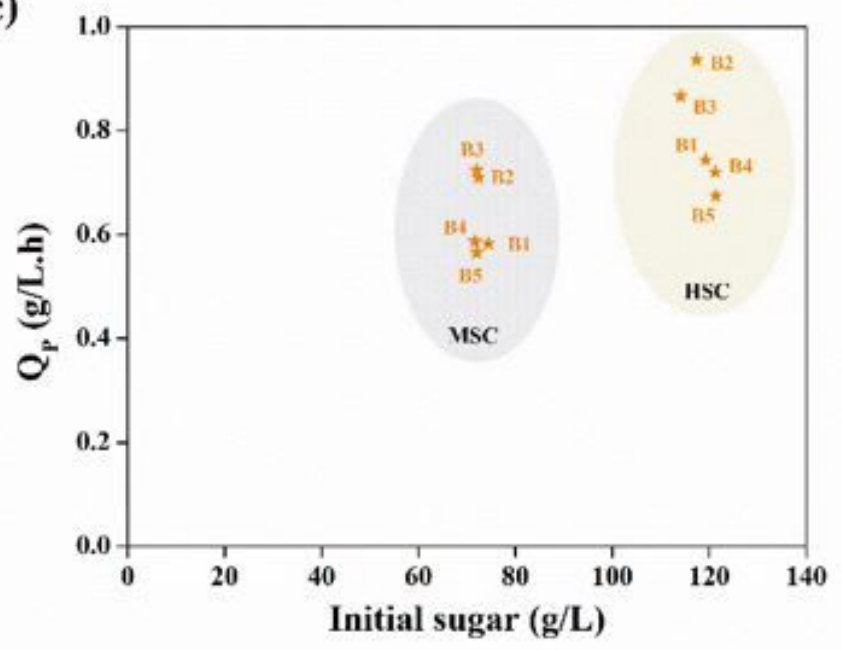

(b)

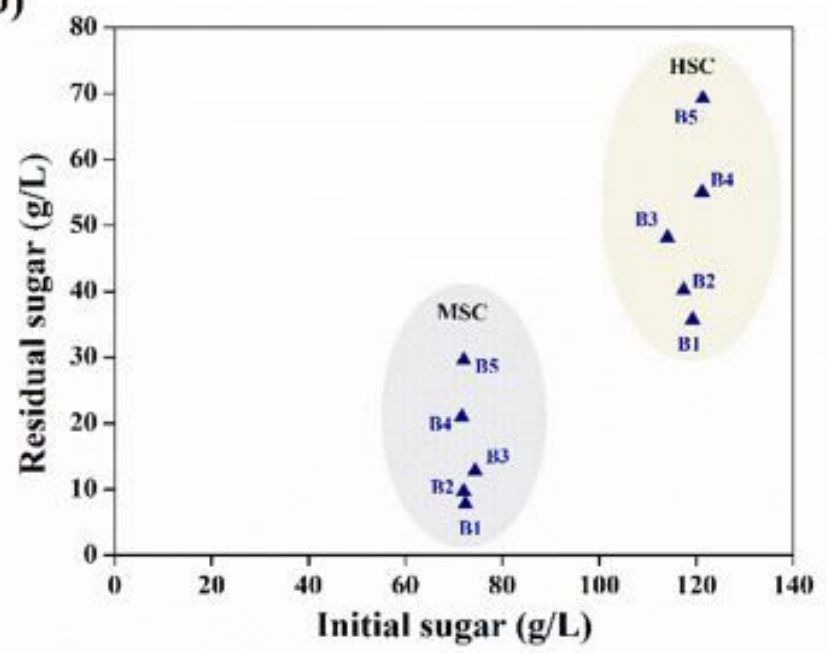

(d)

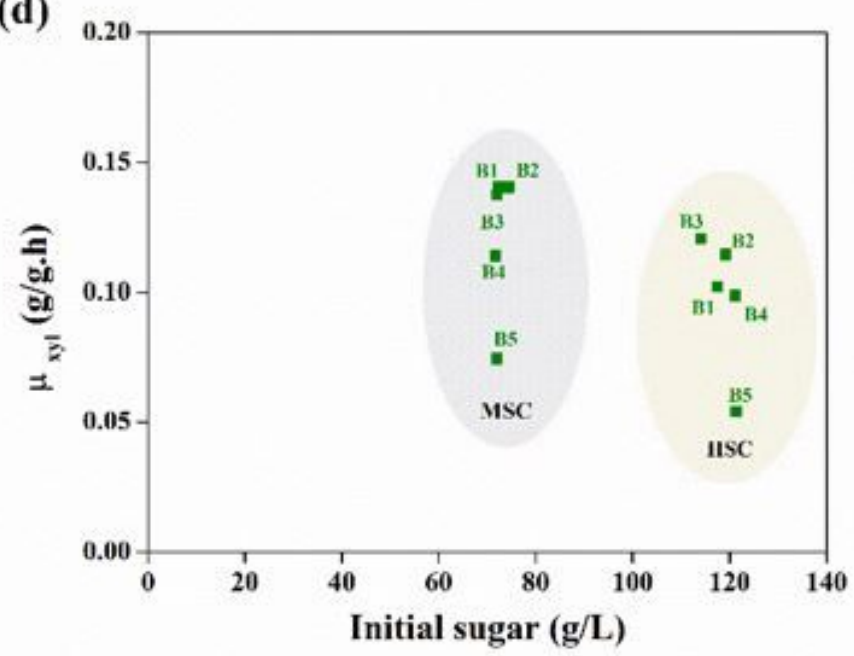

Figure 4

Influence of the initial sugar concentration in (a) modified conversion factor ( $\left.Y^{\prime} P / S\right)$, (b) residual sugar concentration, (c) productivity (Qp) and (d) maximum specific xylose uptake rate ( $\mu x y$ lose) for $S$. passalidarum immobilized in calcium alginate through SBF 


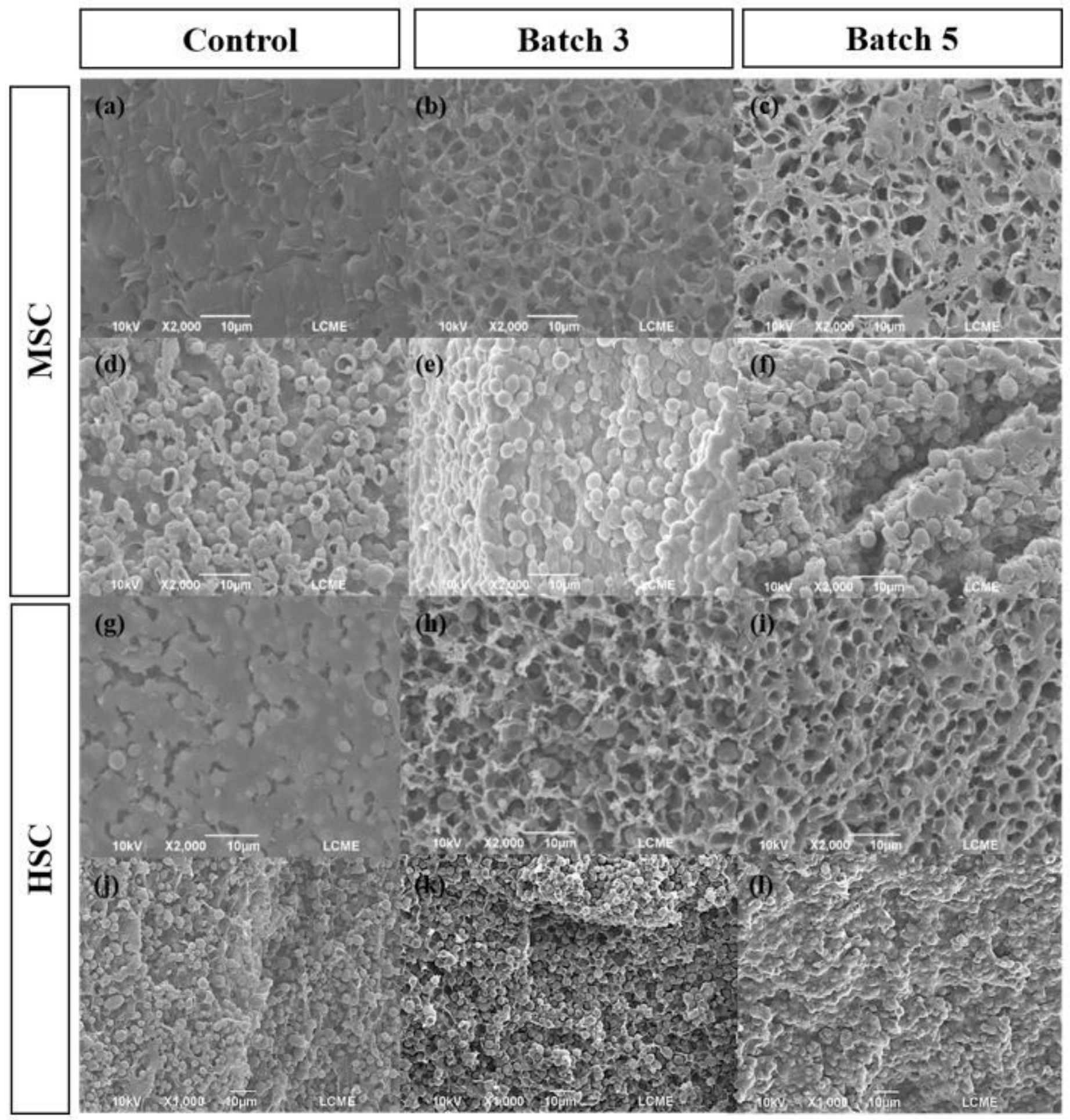

\section{Figure 5}

Morphological analysis of the alginate beads before any batch (Control), after three batches (Batch 3) and after five batches (Batch 5), where (a) MSC control external surface, (b) MSC after batch 3 external surface, (c) MSC after batch 5 external surface, (d) MSC control internal surface, (e) MSC after batch 3 internal surface, (f) MSC after batch 5 internal surface, (g) HSC control external surface, (h) HSC after 
batch 3 external surface, (i) HSC after batch 5 external surface, (j) MSC control internal surface, (k) HSC after batch 3 internal surface, (I) HSC after batch 5 internal surface 